\title{
Consolidating Colonial Rule: Detentions in the Gold Coast and Sierra Leone, I896-I90I
}

I 896 and I 897 were significant years in the consolidation of British rule both in the Gold Coast and in Sierra Leone. In I 896, Asante, which had for so long been a troublesome African neighbour to the British colony and protectorate at the Gold Coast, was conquered by a military expedition which deposed and deported the Asantehene, Kwaku Dua III, more commonly known as Prempeh. In the same year, a protectorate was proclaimed over the territories adjacent to the colony of Sierra Leone, which the French and British had agreed to be within the latter's sphere of influence. Britain's attempt to raise revenue for its new administration in Sierra Leone prompted a rebellion - the 'Hut Tax war' - which also ended in the detention and deportation of a number of local leaders, the most prominent of whom was Bai Bureh.

In contrast to the expansion of British rule in the Niger delta, which took place under the direction of the Foreign Office, in these areas it was the Colonial Office which took political responsibility. British policy in the Oil Rivers region was informed by a changing view of the relationship between the imperial state and the rulers of protected polities, with officials increasingly considering protectorates as in some way subject to imperial power. It was because of such views that officials in those areas felt free to try men like Nana Olomu or Ovonramwen in ways which were of questionable legality, but which seemed to those officials to justify their detention or deportation. By contrast, in the areas further up the coast, where the Colonial Office was master, there was less evidence of this kind of shadowy mi-souveraineté. 
Instead, in these areas there was a stark contrast between the approach taken in Asante, where the British had not yet established any kind of jurisdictional foothold, and in Sierra Leone, where an Order in Council implementing the Foreign Jurisdiction Act had been passed, and a new system of administration set up.

As shall be seen, in Asante, the deposition and detention of Prempeh, largely orchestrated and driven by the local Governor, was treated in the manner of an act of state, arising out of war. Legal concerns played very little part in the events leading to his detention, even though the Governor made sure - for his own political reasons that Prempeh's closest adviser would be subjected to an ordinary trial for an ordinary crime. By contrast, in Sierra Leone, where the British had already established their authority by the time of the revolt, officials were highly law-minded, striving to find adequate legal means to deal with the rebels. In the end, it was their realisation that they lacked the full jurisdiction they wanted that led them to detain Bai Bureh, rather than to try him.

\section{The Deposition of Prempeh of Asante}

Prempeh, the king of Asante, whose long exile in the Seychelles would not end until I924, became the best known of all the West African deportees. ${ }^{\mathrm{I}}$ Formally installed on the Golden Stool of Asante in June I894 as King Kwaku Dua III, having been elected to that

I William Tordoff, 'The Exile and Repatriation of Nana Prempeh I of Ashanti (I896-I924)', Transactions of the Historical Society of Ghana, vol. 4 (I960), pp. 33-58; William Tordoff, Ashanti under the Prempehs, I888-I935 (Oxford, Oxford University Press, I965); Adu Boahen, 'Prempeh I in exile' in Toyin Falola (ed.), Africa in the Twentieth Century: The Adu Boahen Reader (Trenton, Africa World Press, 2004), pp. 355-370; Adu Boahen, 'A Nation in Exile: The Asante on the Seychelles Islands, I900-24', in Enid Schildkrout (ed.), The Golden Stool: Studies of the Asante Centre and Periphery (Washington: American Museum of Natural History, I987), pp. I46-I60; Joseph K. Adjaye, 'Agyeman Prempe I and British Colonization of Asante: A Reassessment', International Journal of African Historical Studies, vol. 22:2 (1989), pp. 223-249; Ivor Wilks, Asante in the Nineteenth Century: The Structure and Evolution of a Political Order (Cambridge, Cambridge University Press, 1975); and Thomas Lewin, Asante before the British: The Prempean Years, I875-I900 (Lawrence, Regents Press of Kansas, I978). See also A. Adu Boahen, Emmanuel Akyeampong, Nancy Lawler, T. C. McCaskie and Ivor Wilks (eds.), "The History of Ashanti Kings and the Whole Country Itself" and Other Writings, by Otumfuo, Nana Agyeman Prempeh I (Oxford, Oxford University 
position six years earlier, he was deposed by the British in January I 896, and detained in Elmina Castle, along with twelve others. One year later, the detainees were transferred to Freetown, and in August 1900, they were moved to the Seychelles, where they would soon be joined by a tranche of new political prisoners exiled after the revolt led by Yaa Asantewaa. His detention and removal was part of a policy to consolidate British control over Asante.

The Kingdom of Asante, which seemed slowly to be falling to pieces after the war of I873-1874, began to revive under Prempeh, an independent-minded ruler who showed little interest in being taken under British protection. When Governor Griffith of the Gold Coast sent a commissioner to Kumasi with a draft treaty in I89I - without first asking London - Prempeh rejected it, declaring that 'Ashanti is an independent kingdom. ${ }^{2}$ Instead, he sought to bring together the various Asante states which had seceded in the previous years, a policy which bore fruit when he was formally enstooled as Asantehene with the support of the Amantoo states. ${ }^{3}$ Equally worryingly for the British, Prempeh also wanted to open up a trade route to the sea without passing through land under their influence. ${ }^{4}$ When Prempeh took military action to effect this in the summer of 1893 , Britain offered treaties of protection to rulers in these areas, and warned Prempeh that they would retaliate if he attacked them. ${ }^{5}$ Although this threat was enough to make Prempeh back down, ${ }^{6}$ British officers on the ground considered that it might be necessary to take the whole of Asante into the protectorate. Acting Governor F. M. Hodgson also advised a policy 'to hasten the annexation of Ashanti', and proposed in November that an ultimatum backed by the threat of force be issued to Prempeh. ${ }^{7}$

Press, 2003); and R. S. S. Baden-Powell, Downfall of Prempeh: A Diary of Life with the Native Levy in Ashanti, I895-96 (London, Methuen \& Co., I900).

${ }^{2}$ PP I896 (c. 7917) LVIII. 455, enc. I in No. I6, p. 70.

3 Francis Agbodeka, African Politics and British Policy in the Gold Coast, I868-I900: A Study in the Forms and Force of Protest (London, Longman, I97I), pp. I 53-I 58. Britain did not recognise his status, claiming that the kings of Kokofu and Mampon were not present, and so continued to refer to him as the king of Kumasi: PP I896 (c. 79I8) LVIII. 707, No. 25, p. 4I at p. 42.

4 Agbodeka, African Politics and British Policy, pp. I6I-I 66.

${ }^{5}$ PP 1896 (c. 7917), Nos. 26-27, p. 82.

${ }^{6}$ PP I 896 (c. 7917), No. 33, p. 96; No. 34, p. 99; No. 36, p. Iо०.

7 PP I 896 (c. 7917), No. 42, p. IOI; No. 44, p. I 20 ; enc. I in No. 44, p. I 22. 
However, the Secretary of State, Lord Ripon, would not countenance a policy which required the backing of troops. Instead, he suggested a 'via media', whereby Prempeh would be asked to receive a British 'agent', who would settle disputes between the different tribes and promote the development of trade, without interfering in domestic matters. ${ }^{8}$ A proposal to this effect was made in February I $894,{ }^{9}$ but over the summer it became increasingly clear that the authorities in Kumasi had no desire to submit to British protection, although they did not rule out the kind of relationship which existed between the British crown and the Emir of Afghanistan. ${ }^{\text {IO }}$ Instead of sending the Governor an answer, the Asante planned to send an embassy, led by Prempeh's Prime Minister, the younger John Owusu Ansa and his brother Albert, to present their case in London. Griffith, who felt that it would be a waste of time to deal with the Ansas, thought that strong measures should be taken 'to compel the obedience of Ashanti to Imperial control'. ${ }^{\text {II }}$ When Prempeh's representatives arrived in Accra in December, he told them that the Queen would never receive a mission from a ruler accused of human sacrifice ${ }^{\mathrm{I} 2}-$ an allusion to press reports (denied by the Asante) that 400 people had been sacrificed at Prempeh's enstooling. ${ }^{13}$ However, his attempt formally to forbid them from going to England failed: ${ }^{\mathrm{I}}$ and when Griffith sent messengers to Kumasi in January to demand Prempeh's response to the proposal for a Resident, they were told that his response was in the hands of his ambassadors, who would deliver it to the Queen. ${ }^{\text {I5 }}$

Griffith continued to advocate a policy of taking complete control of Asante 'by promptly dealing a crushing blow to that country'. ${ }^{16}$ Like Hodgson, he was aware that a pretext for intervention could be found in the Asante's breaches of the treaty of Fomena of I 874: in particular,

${ }^{8}$ PP I896 (c. 79I7), No. 53, p. I47.

9 PP I896 (c. 7917), enc. 2 in No. 67, p. I67; enc. in No. 77, p. 179.

ro Wilks, Asante in the Nineteenth Century, p. 640. On 5 October I 884, Prince Albert Owusu Ansa wrote to Griffith that it was essential that Britain formally acknowledge Asante as independent and enter a similar understanding to that with Afghanistan: PP I 896 (c. 7917), enc. I in No. 97, p. 2 II.

${ }^{\text {II }}$ PP 1896 (c. 7917). No. I00, p. 214. His view was shared by other officials on the ground: encs. 3 and 4 in No. IOO, pp. 222, 223.

${ }^{12}$ PP 1896 (c. 7917), No. I08, p. 235 ; No. I10, p. 237.

${ }^{13}$ PP I 896 (c. 7917), No. 94, p. $206 .{ }^{14}$ PP I 896 (c. 7918), enc. 5 in No. 4, p. I 5.

${ }^{15}$ PP I 896 (c. 7918), No. 7, p. $20 .{ }^{\text {I6 }}$ PP I 896 (c. 7918), No. I2, p. 22. 
the fact that only I,000 ounces of 50,000 due as an indemnity under that treaty had been paid. ${ }^{17}$ Furthermore, although the Colonial Office remained reluctant to commit itself to a military solution, it began to prepare for this eventuality. Instructions were given to the new Governor of the Gold Coast, William Maxwell, that, if the king continued to refuse to come to a peaceful settlement (accepting a British Resident), he was to remind him of his breaches of the treaty, which could be followed by an ultimatum, backed by force. ${ }^{.8}$ On 23 September I 895 , the ultimatum was sent, with a deadline for the reply set for the end of October. ${ }^{19}$ In the meantime, the Asante envoys in London found neither the Colonial Office nor the Foreign Office receptive to their requests for meetings. ${ }^{20}$ They did, however, enter into an agreement with a British entrepreneur, George Reckless, to grant a concession for the development of Asante to a new chartered company, on the model of the British South Africa Company. Since the concession provided for the establishment of a Resident Agent and courts, the envoys thought that all Britain's reasonable demands for the development of the country had been met. However, the Colonial Office declined to recognise any concession made by them. ${ }^{21}$

When the deadline passed, preparations were made for a military expedition to be sent, even though Britain's policy aims remained at best hazy. As the Secretary of State Joseph Chamberlain explained, had Prempeh simply accepted the terms of the ultimatum, London would have been satisfied with the establishment of a Resident. However, once it became necessary to send a military force, it would no longer be possible to allow Prempeh to remain in his position. Instead, some sort of new administration would have to be set up. Although Chamberlain

${ }^{17}$ PP I896 (c. 79I8), enc. I in No. 4, p. 6. ${ }^{18}$ PP I896 (c. 79I8), No. 25, p. 4I.

I9 PP I896 (c. 7918), No. 62, p. 99; enc. I in No 77, p. I05. See also CO 879/43/I, No. 46, p. 62 at pp. 65,67 (redacted in PP I 896 (c. 7918), No. 45, p. 83).

20 They sought the assistance of H. C. Richards MP, who presented the Colonial Office with a memorandum from them. PP I 896 (c. 791 8), No. 52, p. 92. London's response was that they were going to deal directly with the king in Kumasi, and that, if the embassy wished to be of use to him, they ought to return. The government regarded Prempeh as only the head of a tribe, with no standing to send ambassadors: PP I 896 (c. 79I7), No. IIO, p. 237.

${ }^{21}$ PP I896 (c. 79г8), No. 79, p. I07; No. 95, p. II6. The concession is in PP I896 (c. 7918), enc. in No. 82, p. I09. See also Wilks, Asante in the Nineteenth Century, p. I07; and Lewin, Asante before the British, p. I9I. 
left it to the Governor to submit proposals on its shape, ${ }^{22}$ he also told his officials in late December that 'Ashanti should be practically annexed to the Colony with provisions ensuring a certain amount of independent control to the different chiefs. ${ }^{, 23}$ At the same time, both he and his officials realised that any annexation might raise difficult questions about how to deal with the continuing existence of slavery in Asante. When Maxwell had sent his ultimatum to Prempeh, he had instructed his messengers to reassure the king, if he raised the question of slavery, that the Resident would 'not interfere with the institutions of the country'; ${ }^{24}$ but this kind of policy would become impossible if Asante were annexed into the colony, since it would become subject to the Gold Coast's Ordinance No. 2 of I 874, which forbad slavery. Given that this ordinance had not been applied in other Asante areas which had come peacefully into the protectorate, Augustus Hemming thought that 'we should not press for it immediately, as it would probably upset the whole domestic system of the country.' Seeking guidance on this, Chamberlain telegrammed Maxwell on I 3 January asking both whether Asante should be annexed to the protectorate and whether it should be exempt from the slavery ordinance. ${ }^{25}$ On I9 January (by which time he had arrived in Kumasi), Maxwell sent an ambiguous reply:

Referring to your telegram of $\mathrm{I} 3^{\text {th }}$ January recommend[ing] British Protectorate, Ashanti. If Prempeh detained as prisoner, it will be necessary to limit jurisdiction Supreme Court so that Chiefs and others may not be summoned to Cape Coast Castle. Have no doubt that I can satisfy Chiefs about operation of Ordinance No. 2 of 1874 , which is practically little put in execution in remote districts recently acquired. ${ }^{26}$

One source of ambiguity in this telegram was the fact that the word used in the cipher code meant both 'recommend' and 'recommending', so that officials in London were unsure whether he was advising taking Asante into the protectorate, or thought that it was London's policy. ${ }^{27}$

${ }^{22}$ PP 1896 (c. 79I8), No. 90, p. II3; cf. PP I896 (c. 79I8), No. 87, p. II 2 (redacting a passage relating to the ultimate need to make treaty provisions against slave raiding: CO 879/43/I, No. I I9, p. I I I). See also PP I 896 (c. 79 I 8), No. I I 5, p. I 27 at p. I 28.

${ }_{23} \mathrm{CO} 96 / 262 / 22687 .{ }^{24} \mathrm{CO} 879 / 43 /$ I, enc. 2 in No. 86, p. 97 at p. 98; No. II9, p. II I.

${ }_{25}$ Minute 26 December I895, CO 96/262/22687; CO 879/44/7, No. I6, p. Io.

${ }^{26} \mathrm{CO} 879 / 44 / 7$, No. 27 , p. I7.

${ }^{27}$ Minute by R. Antrobus, 20 January I 896, CO 96/270/I42I, f. 85. 
Even at this late moment, neither London nor Accra had any clear idea what the future relationship between Asante and the Gold Coast would be.

Nor did the British have a consistent set of demands to put to Prempeh. When Prempeh answered Maxwell's demands in early November by referring to his envoys in London, the Colonial Office saw this as 'simple defiance' and as a rejection of the ultimatum. It confirmed Chamberlain in his view that a military expedition had to be sent, to secure complete British control in Asante, imposed by force if need be. ${ }^{28}$ At the same time, however, negotiations continued in London with the agent of the envoys, the barrister Thomas Sutherst, who reported that they were ready for a British Resident to be installed at Kumasi. Preparations for the military expedition continued, in part because the Colonial Office did not trust the envoys' authority. At this point, a new demand was added by the British, requiring the king to pay the costs incurred in preparing the expedition. Through Sutherst, the envoys accepted the British demands, and also agreed to pay the full I 874 indemnity, albeit with the payment spread over time. ${ }^{29}$ In light of these concessions - and given the risk that Prempeh might 'be driven to fight thinking that we mean in any case to attack him' - Chamberlain wanted the king reassured that the 'expedition will be a peaceable one if he submits $\&$ accepts terms of ultimatum'. ${ }^{30}$

If the Secretary of State was veering to the view that Prempeh might already have conceded all that was needed, his Governor in Accra was not. When two of Prempeh's envoys, Kwame Boatin and Kwaku Foku, returned to Cape Coast in the middle of December, they were given a message for Prempeh from Maxwell that he would have to recognise the independence of tribes seeking British protection, pay the cost of the expedition, give land for a fort, and supply hostages as security for fulfilment of the treaty conditions. ${ }^{3 \mathrm{I}}$ By the end of the year, Maxwell and Chamberlain had agreed that Prempeh would not be deposed if he

${ }^{28}$ Minute by Augustus Hemming, I3 November I 895, CO 96/262/20074; PP I 896 (c. 79 I 8), No. 97, p. I I6; No. I04, p. I 20; No. I35, p. I4 I; No. I I4, p. I 26; No. I I 5 , p. 127.

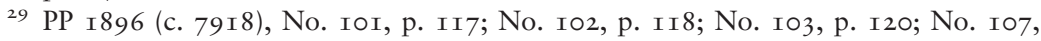
p. I2I. Although Sutherst at first queried the expenses of preparing an expedition, his later communication signalled a 'complete acceptance' of British terms.

${ }^{30}$ Minutes by Chamberlain and Meade, 24 November I 895, CO 96/262/20868.

${ }^{31} \mathrm{CO} 879 / 44 / 7$, No. 22, p. II. 
made a full submission at Kumasi and paid the cost of the expedition; ${ }^{32}$ but, if the Asante resisted, the British would be free to seize the Golden Stool - which Chamberlain assumed would increase the prestige of the British government in African eyes - and make Prempeh's rival Yaw Twereboanna king of Kumasi. ${ }^{33}$ When the expeditionary force set off for Kumasi in January, it took a draft treaty containing the terms set out to Boatin and Kwaku Foku. ${ }^{34}$ With the expedition en route, the Asante desperately sought to make concessions, sending messengers offering the required hostages, and agreeing to all demands, save that of paying the (unaffordable) costs of the expedition. However, Maxwell insisted that the terms of the treaty would have to be dictated at Kumasi, once he had arrived.

\section{The Arrest of Prempeh}

When the imperial troops arrived in Kumasi on Friday I7 January I 896, accompanied by the sound of bugles and drums, there was no resistance by the Africans, who welcomed them with tomtoms. Maxwell had made plans to seize and detain 'the palace party' (including Prempeh and his parents) in case they did not comply with the government's full demands, which included an immediate payment of 50,000 ounces of gold towards the war indemnity. Faced with Maxwell's demands, Prempeh offered to pay an instalment (since he could not pay it all), and to make a private submission. ${ }^{35}$ Maxwell stuck to his terms. He considered Prempeh insolent, and thought that the Asantehene assumed that the British could be bought off with a small payment. In fact, Prempeh was prepared to concede, even if he was not permitted to save face. When a deadline set for his submission expired on the Monday, Prempeh made the necessary public concession, grasping Maxwell's feet 'in the attitude of a suppliant'. ${ }^{36}$ However, since he still offered only 680 ounces of gold, he was immediately detained along with thirteen other chiefs then present, and moved to Cape Coast. The decision to detain Prempeh had been Maxwell's alone; but once it had

\footnotetext{
32 CO 879/44/7, No. 72, p. 45. ${ }^{33}$ CO $879 / 44 / 3$, No. 53 , p. 22.

$34 \mathrm{CO} 879 / 44 / 7$, No. 64 , p. 35 and enclosures. ${ }_{35}$ CO $879 / 44 / 7$, No. 98 , p. 70.

${ }^{36} \mathrm{CO} 879 / 44 / 7$, No. 83 , p. 49 at p. 50 . Wilks, Asante in the Nineteenth Century, p. 657.
} 
been reported in the press as 'an unqualified success', ${ }^{37}$ it was impossible for the Colonial Office to reverse.

Maxwell immediately informed London of the detentions, and of the fact that he had sent instructions for an ordinance to be passed legalising them, and suggested that Prempeh and his chiefs be deported to Sierra Leone. ${ }^{38}$ Officials in the Colonial Office were troubled by the policy which was being made on the ground. As Chamberlain wired to Maxwell, 'Deportation or detention as political prisoners not contemplated by ultimatum. ${ }^{39} \mathrm{He}$ and his officials were also troubled by the fact that the Governor was demanding an indemnity the king could not pay. As Chamberlain put it, "'la plus belle fille ne peut donner que ce qu'elle a" $\&$ if he has no money he cannot pay.' ${ }^{40}$ His officials realised that the detention would be hard to justify in parliament if its only purpose was 'to extort more money'. They were prepared to see the detainees taken to Cape Coast Castle in military custody in the short term, but wanted more information. 'The question how long Prempeh \& Co are to be kept at Cape Coast must first be considered before we can authorize an ordinance detaining them as political prisoners', Meade minuted, 'The shorter the detention the better.' ${ }^{4 \mathrm{I}}$ The same official later commented, 'I fear it will not be easy to justify getting rid of Prempeh - however desirable.' ${ }^{42}$

Maxwell explained his approach in two despatches, one written on the day of the detentions and one a week later. In his view, taking the king prisoner was the only way to demonstrate that Britain's paramount influence had been established in Asante. To have accepted the mere assurances from a 'frightened but unpunished savage' would have rendered the expedition abortive and emboldened the Asante. ${ }^{43}$ The decision to detain was taken both 'as a measure of punishment in

37 Manchester Guardian, 2I January I896, p. 8. The report stated, 'King Prempeh is neither an imposing nor an attractive monarch. In fact he is little better than a drunken sentimentalist.' See also Manchester Guardian, 23 January I896, p. 8; and The Times, 23 January I896, p. 5; 29 February I 896, p. I 5 .

${ }^{8}$ CO $879 / 44 / 7$, No. 28 , p. I7; No. 30 , p. I 8.

39 Chamberlain to Maxwell, 22 January I 896, CO 879/44/7, No. 37, p. 20.

$4 \circ$ Chamberlain minute, 2I January I 896, CO 96/262/I 470 f. 89 . Bramston reminded Chamberlain of his telegram of 3 I December, telling Maxwell that, if the king hesitated to pay expenses, new terms could be imposed: $\mathrm{CO} 879 / 44 / 3$, No. Io0, p. 46.

${ }^{4 \mathrm{I}}$ Minute, 2I January I 896, CO 96/262/I486.

${ }_{42}$ Meade minute, 9 February I 896, CO 96/270/2933, f. 67.

${ }^{43} \mathrm{CO} 879 / 44 / 7$, No. 83 , p. 49 at p. 50. 
default of payment of a reasonable sum on account of the expenses of the expedition and as the only possible means of securing that complete and efficient British control at Kumasi which has been declared by Her Majesty's Government to be indispensable.' In Maxwell's view, there could be no settlement of affairs in Asante unless these political prisoners were 'deprived of all power to interfere with the gradual establishment of a better state of things by being kept for some years in a place where they can do no mischief'. ${ }^{44}$ In a private letter to John Bramston (assistant undersecretary of state), he added that the instructions he had been given in the despatch of 22 November, which allowed him to dictate terms if force were required, had left him considerable latitude. ${ }^{45}$ More significantly, Maxwell revealed how he was influenced by his earlier colonial experiences. Before his appointment to the Gold Coast in I 895, he had spent most of his career in the Straits Settlements (where his father was chief justice). While a deputy commissioner, Maxwell was decorated for his part in the expedition against the killers of J. W. W. Birch, the British Resident at Perak, which resulted in the deportation of Sultan Abdullah. Looking back on this, he told Bramston that British attempts to bring civilisation and law and order to the Malay states had been impeded by 'underhand opposition' on the part of Rajas and chiefs; and that British success in the peninsula after I 876 had been rendered effectual by their removal. 'With this experience', he wrote, 'I know that the removal of the elements of mischief is expedient and indeed absolutely necessary. ${ }^{46}$ Given his explanations, the Secretary of State approved his actions, and expressed his appreciation of the prompt and decisive action taken. ${ }^{47}$

Prempeh had been detained and removed before any ordinance had been drawn up, but Maxwell felt justified in holding him as a prisoner of war, having issued a declaration under section I89 of the Army Act in December. ${ }^{48}$ However, he was advised by his Attorney General,

44 CO $879 / 44 / 7$, No. 98, p. 70 at pp. 72,75 .

45 Maxwell to Bramston, 29 January I896, CO 96/270/48I4, referring to PP I896 (c. 7918), No. II 5, p. I 27.

${ }^{6}$ Maxwell to Bramston, 29 January I 896, CO 96/270/48I4.

47 CO $879 / 44 / 7$, No. I05, p. 87.

$4^{8} \mathrm{CO} 879 / 44 / 7$, No. 83 , p. 49 at p. 5 I. In October I 896, a Colonial Defence Order in Council was issued which empowered Governors in certain named colonies to issue proclamations subjecting all people in the colony to the Army Act. However, the only African colony in which this applied was Sierra Leone: CO 323/I 594/3. 
William Geary, that, since Prempeh's position as a prisoner of war was doubtful and since the Army Act provision (which was designed for camp followers) did not apply to him, it would be wise 'ex majore cautela to pass the usual Ordinance'. ${ }^{49}$ The ordinance was duly passed by the Legislative Council on 23 January, and assented to by the Governor eleven days later. It retrospectively legalised all acts done in connection with the arrest and detention of Prempeh and his supporters, and authorised their further detention or deportation..$^{50}$ A second ordinance had to be passed by the legislative council on 28 January, since Maxwell had omitted to send down all the names of those political prisoners being detained: this second ordinance legalised the detention of six Asante, in addition to the seven whose detention was already provided for. ${ }^{51}$

\section{The Trial of John Owusu Ansa}

One reason why the British sent their military force to Kumasi rather than accepting the king's concessions was the continued uncertainty over the status of the envoys led by John Owusu Ansa. Ansa himself arrived back on the Gold Coast on 27 December, eleven days after the other envoys. When he met the Governor, Maxwell demanded to see his credentials as the king's representative, only to discover that Prempeh had not authenticated them himself, but that the mark had been made at Cape Coast by Ansa and the king's linguist, Kwaku Foku, and the seal later added in London. ${ }^{52}$ On discovering this, Maxwell refused to have anything further to do with Ansa, and referred the matter to the Attorney General. ${ }^{53}$ The apparent flaw in Ansa's credentials was reported to the Colonial Office, which released Maxwell's telegram to the press, with the warning that the government would not recognise any concessions purportedly granted by Ansa. ${ }^{54}$

$49 \mathrm{CO} 879 / 44 / 7$, enc. 3 in No. II 2, p. 90 . 50 CO $879 / 44 / 7$, No. I I 2, p. 89.

${ }^{51} \mathrm{CO} 879 / 44 / 7$, No. II 3 , p. 9 I.

${ }_{52} \mathrm{CO} 879 / 44 / 3$, no. 92, p. 38 ; CO $879 / 44 / 7$, No. 45 , p. 23.

$53 \mathrm{CO} 879 / 44 / 7$, No. 46 , p. 29 . The enclosed report confirmed that he could be prosecuted in the colony for forgery and possibly for fraud and false pretences.

54 The Times, 3i December I895, p. 3; and Daily Telegraph, 3 I December I 895 ('The Sham Ambassadors: Forged Credentials'). 
John and Albert Owusu Ansa were among those arrested by Maxwell at Kumasi on 20 January. Rather than being detained, they were sent back to the coast to stand trial in the colony for forging the king's credentials. ${ }^{55}$ Although Bramston regarded these arrests as a mistake, ${ }^{56}$ Maxwell replied that their prosecution had been requested by the Asante war chiefs, who 'demanded punishment of Ansahs for being [the] cause of [the] present difficulties' ${ }^{57}$ One month later, Maxwell visited the detainees at Elmina Castle. Perhaps sensing the chance of securing their own release, they now sought to put the blame on Ansa. At the meeting, Asafu Boachi, one of the war chiefs who had accused the Ansas when Maxwell was at Kumasi, spoke for the king. He said that the Asante had wanted to agree to the British terms, but that John had refused to agree to this. He added that Ansa had not been appointed ambassador, his trip to England had been disapproved, and he had no authority to grant concessions. Prempeh himself then spoke: 'I have had no hand in the whole thing', he announced: 'Ansah deceived me. I never authorised him to go to England, and I want to beg the Governor to have this case decided for me. ${ }^{58}$ While these words did not secure the prisoners' release, they certainly fortified the determination of the authorities in Accra to press on with the prosecution.

The prosecution was designed to portray the Ansas as private adventurers, who wanted to make personal profits by selling concessions in the king's name. ${ }^{59}$ The authorities in the Gold Coast had long thought that Ansa was living a life of luxury, paid for by a deluded king who thought that his envoy could do anything for him. They now sought to uncover any other material which might

$55 \mathrm{CO} 879 / 44 / 7$, No. 83, p. 49.

${ }^{56}$ Minute, 2I January I 896, CO 96/262/I486. Antrobus also doubted 'whether it was worth while to prosecute him, unless Mr Maxwell has done it to keep him from making mischief in Ashanti': 24 January I 896, CO 96/263/1696.

57 CO $879 / 44 / 7$, No. 52, p. 33 . Under these circumstances, the Colonial Office had to concede, but was still sceptical: Bramston minute, 24 January I896, CO 96/270/ I 83 I.

$5^{8} \mathrm{CO} 879 / 44 / 7$, enc. 2 in No. 229, pp. 2 I I, 2 I 6.

59 Bramston came to think that both Sutherst and Ansa were anxious to prevent Prempeh's overthrow because they needed him to confirm their concessions, which made him observe, 'What a lot of rogues!' I9 March I896, CO 96/270/5916. 
incriminate John, including potential bigamy charges. ${ }^{60}$ Although the brothers were to be tried for an ordinary crime, the Gold Coast authorities were very aware of their political importance, and Acting Governor Hodgson asked for permission to detain them as political prisoners 'in the interests of pacification of Ashanti' in case of their acquittal. Chamberlain's reply was there were no sufficient grounds for detaining them as such, but that they should not be allowed to proceed to Asante. ${ }^{61}$ If this was a sign that the Colonial Office did not feel that it was appropriate to redetain after an acquittal (at least in this case), the legal basis for preventing their return to Kumasi was unclear.

The trial began with the Ansas challenging the court's jurisdiction: as they were the ambassadors of a foreign state, they claimed not to be subject to arrest by the colonial authorities. The crown's lawyer answered this by arguing that international law applied only to civilised states and not to barbarous ones; and adding that, even if this were not the case, only ambassadors recognised as such by the host state could claim such protection. The Ansas also argued that their arrest and rendition to Cape Coast was unlawful, both because Kumasi was beyond the Gold Coast's jurisdiction and because there had been no warrant to authorise it. The trial proceeded after the court had decided to reserve any questions as to the jurisdiction, to be determined in the event of a conviction. The crown called Kwaku Foku and Boatin as witnesses. Contradicting what Ansa had said on his return, they denied having seen the document until they visited Sutherst's home in London. ${ }^{62}$ However, they did testify that they had been sent to England by the king, and that Prempeh had conferred full power on Ansa to use his discretion. The brothers were duly acquitted by the jury. Fearing another acquittal, the Attorney General decided not to proceed with a second set of charges, after the judge made it clear that he agreed with the verdict. Reflecting on the case, Geary told Acting Governor Hodgson that the verdict 'in a certain way tells

${ }^{60}$ CO $879 / 44 / 7$, No. I23, p. I 20; CO $879 / 44 / 7$, No. I IO, p. 88 . London was not keen on these investigations: Minute by Bramston, I 8 March I896, CO 96/270/59 I 8 .

6I CO 879/44/7, No. I74, p. I 59; No. I 80, p. I60.

${ }^{62}$ This might have cast doubt on the prosecution's allegation that the offence had been committed in the Gold Coast. 
in favour of the dethronement of King Prempeh, as it shows that he preferred to elect to send the Ansahs to England on the chance of obtaining better terms than to accept the ultimatum by direct communication with the Governor'. ${ }^{63}$ This was in effect to concede that Ansa was indeed acting as the representative of the king. Maxwell, however, continued to insist that the acquittal constituted a miscarriage of justice. ${ }^{64}$

Having been forbidden to return to Asante, the Ansas returned to England in September, to seek compensation for their troubles. ${ }^{65}$ The following spring, Sutherst presented a petition to the Colonial Office on their behalf, complaining that they had been marched from Kumasi to Cape Coast Castle as common criminals, while their property was taken and their homes destroyed. ${ }^{66}$ Having already been told by Maxwell that the Ansas had only been given authority to act as translators and that they had been seeking personal gain, ${ }^{67}$ the Colonial Office batted away the petition, on the ground that there had at least been a case to answer. ${ }^{68}$ The Ansas did not leave it at that. In a further letter, they reiterated that they had been arrested without warrant in an independent country over which the British had no jurisdiction, and had been charged with some offences (such as stealing from Prempeh) which could not be cognisable in Her Majesty's Courts. Moreover, they asked, 'does Her Majesty's Government maintain that in these days the property of any person charged with a criminal offence, and who is duly tried and acquitted, is liable to confiscation?" ${ }^{69}$ At Chamberlain's request, more information was sought relating to the alleged destruction of Ansa's property, but Maxwell denied that any of it had been confiscated or destroyed by the government. ${ }^{70}$ Unable to return to Asante, the Ansas remained in England, still seeking to recover their lost assets, and taking libel proceedings against various newspapers for comments made when publishing Maxwell's telegram calling in question the authenticity of

${ }^{63} \mathrm{CO} 879 / 44 / 7$, enc. in No. I99, p. I73 at p. I76.

${ }^{64}$ Maxwell to Colonial Office, I3 October I 896, CO 879/44/7, No. 216, p. I94.

${ }_{65} \mathrm{CO} 879 / 44 / 7$, No. 21 5, p. I9I; Manchester Guardian, 30 October I896, p. 7 .

${ }_{66}^{6} \mathrm{CO} 879 / 49 /$ I, No. 2I, p. 25 , and enclosed petition. $\quad{ }^{67} \mathrm{CO} 879 / 44 / 7$, No. 2 I 6, p. 194.

${ }^{68} \mathrm{CO} 879 / 49 / \mathrm{I}$, No. 22, p. $28 .{ }^{69} \mathrm{CO} 879 / 49 / \mathrm{I}$, No. 27 , p. 30.

${ }^{70} \mathrm{CO} 879 / 49 /$ I, No. 28 , p. 33 ; No. 34 , p. 36. 
their credentials. ${ }^{7 \mathrm{I}}$ The attempts stalled when a bankruptcy petition was brought against John in I $898 .{ }^{72}$

\section{Prempeh's Exile}

Prempeh remained imprisoned in Elmina Castle while Maxwell was setting up a new system of administration in Kumasi. ${ }^{73}$ The British now began to worry about the cost of the military expedition, which had turned out to be far more expensive than had been anticipated when it was decided to make Prempeh pay for it. ${ }^{74}$ In the view of R. H. Meade at the Colonial Office, 'as this is really an expedition largely undertaken in the interests of trade development, it is only fair that the Gold Coast should pay. ${ }^{75}$ Chamberlain agreed that the colony could pay by instalments, but he still wanted to see whether the famed Asante treasures might be located, to help pay for the expedition. ${ }^{76}$ Although little treasure had been found when Prempeh's house was searched at the time of his arrest, ${ }^{77}$ officials remained convinced that there was hidden treasure which had yet to be located, and District Commissioner Hendrick Vroom was sent to Elmina Castle to discuss the outstanding indemnity with Prempeh. When Vroom held out the possibility of a pardon if money were found, Prempeh - who had been allowed to consult Boatin and Kwaku Foku on this matter - sought more concrete assurances that a further payment would secure his release. By now, however, Maxwell had begun to doubt whether any hidden treasure would be located, and suspected that Prempeh's plan was to raise the necessary money by compelling contributions in Asante. Since this would be possible only if the British allowed him

${ }^{71}$ Ansah v. Johnstone, in The Times, 23 April I898 p. 5; 26 April I898, p. 5; 27 April s898, p. I .

$7^{2}$ The Times, I9 October I898, p. I3; and Manchester Guardian, 2 November I 898, p. 3. He had already been sued successfully for arrears of rent for the property he had taken for the embassy: Plowden v. Ansah in The Times, 8 December I896, p. I 5 .

73 CO 879/44/7, No. I I4, p. 93. ${ }^{74}$ Minute, I6 January I 896, CO 96/262/I I9I.

75 Minute, 26 January I 896, CO 96/270/I6I4. $\quad{ }^{76}$ CO 879/44/7, No. 88, p. 6I.

77 The items found were either sent to London, where some were kept back for an exhibition at the Imperial Institute with the rest disposed of by auction, or auctioned to soldiers for souvenirs of their expedition: CO $879 / 44 / 7$, No. 95, p. 64; No. IO2, p. 86 . 
to restore his authority there, it was a plan which was out of the question. ${ }^{78}$

Prempeh remained incarcerated. When Acting Governor Hodgson visited Elmina Castle in July, he 'begged earnestly' to be allowed to return to his country, blaming his troubles on the Ansas. Realising that a return to Asante was impossible, Hodgson suggested that he be deported to Sierra Leone, where he might live under greater freedom. This plan had the advantage that it would help quieten Asante, where there were still expectations of his return. ${ }^{79}$ His enthusiasm to deport Prempeh was bolstered by his discovery that Kwaku Foku and Boatin were levying a $£_{5}$ fee on all Asante traders coming to Cape Coast, to build up a fund to pay lawyers to secure the king's release. Hodgson promptly ordered that they be brought to Accra, and told London that he wanted them to be placed with the other political prisoners, and better still be deported. ${ }^{80}$ It was evident that Prempeh was in touch with supporters in Kumasi, and that he had plans to get legal help. By the end of August, a petition had been drawn up for Prempeh by lawyers instructed by Kwaku Foku and Boatin, once more accepting the British terms and offering to arrange for the payment of the indemnity. ${ }^{8 \mathrm{I}}$ After discussing the matter with Maxwell, when on leave in London, Chamberlain came to the view that Prempeh should be removed to Sierra Leone (along with the other prisoners), and that Kwaku Foku and Boatin should be detained and removed with them, and instructions were sent for the necessary ordinances to be passed. ${ }^{82}$ A measure was accordingly passed in Sierra Leone, which conferred on the Governor the power not only to detain these 'political prisoners', but to commit any of them to Freetown Gaol by warrant, in case they attempted to escape or were guilty of any disobedient or insubordinate

${ }^{78} \mathrm{CO} 879 / 44 / 7$, No. I 50, p. I40. ${ }^{79} \mathrm{CO} 879 / 44 / 7$, No. 205 , p. I 82.

${ }^{80} \mathrm{CO} 879 / 44 / 7$, No. 209 , p. I 83 . When it was discovered that boxes of gold were being collected in Kumasi for Prempeh, Hodgson wanted them to be seized: CO 879/44/7, enc. 2 in No. 210 , p. 185 .

${ }^{81}$ CO $879 / 44 / 7$, No. 2I I, p. I 86, with enclosed petition from Prempeh. In this petition, Prempeh stated that he had sent the Ansas to London as envoys. Maxwell sent a long refutation of material in the petition: $\mathrm{CO} 879 / 44 / 7$, No. 229, p. 207.

${ }^{82} \mathrm{CO} 879 / 44 / 7$, No. 2 I 7, p. I 96 . An Ordinance (No. I 2 of I 896 ) was duly passed at the Gold Coast to authorise their detention on 24 November: CO 879/49/I, enc. I in No. 2, p. 2. 
conduct. ${ }^{83}$ This provision was out of the ordinary, but was explained by the fact that the authorities feared that it might be difficult to obtain a conviction from a Freetown jury in case any charges had to be brought.

Prempeh was told at the end of November that he and the others were to be removed. The news was conveyed by the Acting Chief Justice, Francis Smith, who was told to stress that they were being moved in order to allow them greater liberty. Prempeh was clearly disconcerted by the news, and told Smith that they would prefer to remain under greater confinement in Elmina. He again offered to obey all the commands of the Resident if allowed to return to Kumasi. ${ }^{84}$ It was to no avail. On 3 I December, Kwaku Foku and Boatin were put on board the SS Bakana at Accra, and the following day, the rest were added at Elmina. Maxwell's instructions were that the detainees were to be allowed 'comparative freedom', and that accommodation and an allowance were to be provided, at the expense of the Gold Coast. ${ }^{85}$ The whole party which arrived in Freetown on 5 January was made up of forty-four people, a number which increased when shortly after arrival another son was born to Prempeh. ${ }^{86}$

In the meantime, Prempeh's cause was taken up in the House of Commons by the Irish Nationalist Michael Davitt. He asked why Prempeh had been deposed, after he had been reassured by the British that, if he did not resist and accepted the British terms, matters would be settled amicably. Chamberlain's response drew attention to reports that Prempeh had been seeking the help of Samory - 'a powerful chief who has been slave-raiding in the Hinterland' - to resist the British. ${ }^{87}$ Chamberlain's invocation of the threat of Samory was somewhat disingenuous. Although there had been concerns about the ambitions of this Muslim chief towards the end of I 895 - when some had called for action against Prempeh to forestall any danger of Samory's intervention ${ }^{88}$ - the Colonial Office had not thought that there was any risk of Prempeh obtaining Samory's

${ }^{8} 3$ CO $879 / 49 /$, , No. Io, p. 7. ${ }^{84}$ CO $879 / 49 /$, enc. in No. 3 , p. 4.

${ }_{5} \mathrm{CO} 879 / 49 /$ I, enc. I in No. I3, p. Io. For their 'relative freedom' there, see Tordoff, 'The Exile and Repatriation of Nana Prempeh I', p. 35.

${ }^{86} \mathrm{CO} 879 / 49 / \mathrm{I}$, enc. I in No. I9, p. 2 I.

${ }_{87}$ Parl. Debs., 4th ser., vol. 45, cols. 678-679 (28 January I 897).

${ }^{88}$ For example, Manchester Guardian, 25 September I895, p. 7. 
help. ${ }^{89}$ However, by the middle of 1897 , there was concern that the Kumasi chiefs appointed by Maxwell to administer local affairs were beginning to intrigue with Samory. Furthermore, in June, Vroom reported that he strongly suspected the existence of a secret understanding between Samory and Prempeh's supporters. ${ }^{90}$ Maxwell worried that these chiefs were beginning to meddle in political matters, and contemplated not only depriving them of their powers, but removing them to the coast as political prisoners as well. ${ }^{9 \mathrm{I}}$ Vroom's report also made the Governor rethink the question of how to deal with Prempeh. Seeing that his followers in Kumasi remained disaffected, Maxwell worried that their place of banishment in Sierra Leone was not sufficiently distant from Asante to be safe, particularly since people at the coast were unsettling the minds of the Asante with reports that his release was imminent. In August, he visited Kumasi, telling the chiefs at a public meeting that Prempeh was not returning, and that, if the hope of his return continued to 'unsettle' people, he would have to be removed farther away. The meeting turned out to be a fractious one, when the chiefs asked for Prempeh's return:

opoku mensah: I beg the Governor to let Prempeh come back. It was his father who advised him badly and caused all the mischief.

Governor: Let those who desire to see Prempeh back here pay the sum of $£_{200,000}$, which I demanded of him.

OPOKU MENSAH: I cannot afford to pay the money.

GOVERnOR: Prempeh was not sent away because his father advised him badly, but because he did not pay the money which he said he would pay. OPOKU MENSAH: The Queen of England is rich.

GOVERNOR: It is a waste of time to talk further of this matter. ${ }^{92}$

Although he subsequently recommended that they be removed to the Seychelles, ${ }^{93}$ the impetus to remove them fell away when Asante settled. Prempeh petitioned to be allowed home once more in May I 898, again promising to pay the money claimed in instalments, and to abide by whatever conditions the British government imposed. Governor Hodgson told Chamberlain that, since Asante was not yet at

${ }^{89}$ CO 879/43/I, enc. 2 in No. 86, p. 97 at p. 98 (redacted in PP I896 (c. 7918), enc. 2 in No. 77, p. I06). See also CO 96/262/2 I 444. Contrast Wilks, Asante in the Nineteenth Century, pp. 654-655.

90 CO 879/49/I, enc. in No. 36, p. 39 at p. $43 . \quad{ }^{91}$ CO 879/49/I, No. 36, p. 39.

${ }_{92} \mathrm{CO} 879 / 49 / \mathrm{I}$, enc. in No. 44 , p. 47 at p. 49.93 CO $879 / 49 / 1$, No. 44 , p. 46. 
rest, it was 'most inopportune to consider the question of granting pardon to these political offenders'. ${ }^{44}$ In the middle of the following year, Hodgson told the detainees while on a visit to Freetown that they were not being held because of their failure to pay money owed - since Britain could now raise as much money as it wished in Asante - but because their presence would hinder the peaceful reorganisation of the country. ${ }^{95}$

It was only after another revolt had broken out in Asante in I900 that the decision was taken to move the prisoners to the Seychelles. ${ }^{96}$ In February I900, Chamberlain approved a proposal that the Asante should be taxed, in the form of interest charged on the outstanding war debts of 1874 and $1896 .{ }^{97}$ The trigger for the revolt was a provocative speech made by Governor Hodgson on 28 March, when he went to Kumasi to announce the new annual levy of I6,000 ounces of gold. Hodgson wanted to impress on the Asante that Queen Victoria was now their ruler, and that neither Prempeh nor Yaw Twereboanna would ever rule Asante. He also wanted to locate the Golden Stool of Asante, which had been hidden after Prempeh's deposition. The Governor was aware of the political importance of the stool, and regretted that the British had not secured it in I896, since it provided a rallying point for malcontents against British rule. ${ }^{98}$ 'Why am I not sitting on the Golden Stool at this moment?', the Governor asked the chiefs, 'I am the representative of the paramount power; why have you relegated me to this chair?" 99 After receiving evidence as to the possible location of the stool, Hodgson sent a detachment to find it. Instead of locating the stool, they were faced with armed resistance. ${ }^{\text {100 }}$ The combination of an attempt to secure this most venerated Asante artefact with the imposition of a new tax provoked the last armed

${ }^{94} \mathrm{CO} 879 / 49 / \mathrm{I}$, No. 53 , p. 57.

95 Tordoff, 'The Exile and Repatriation of Nana Prempeh I', p. 36.

${ }^{96} \mathrm{CO} 879 / 62 / 8$, No. 3I4, p. 97. On 30 July, the Administrator of the Seychelles authorised to legislate to permit their detention and on 3 August the ordinance was passed: CO 879/62/8, No. 328 , p. IOI; No. $337 \mathrm{~A}$, p. I04.

97 CO 879/62/IO, No. 6, p. I4.

${ }^{8}$ As he later explained, as long as the Golden Stool remained in the hands of the Ashantis, so long does the power of the king - whether the king exists or not - remain with them'. PP I90I (Cd. 50I) XLVIII. 443, No. 79, p. I Io at p. I I3.

99 PP I90I (Cd. 50I), enc. I in No. 32, p. I6.

roo PP I90I (Cd. 50I), No. 3, p. I; No. 32, p. Iо. 
revolt against British rule, led by Queen Yaa Asantewaa. ${ }^{\text {Ior }}$ By December, the rebel leaders, including the Queen, had been captured. A further ordinance was passed in I90 I to authorise the deportation of fifteen Asante rebels, to join Prempeh in the Seychelles. ${ }^{\text {IO2 }}$

Like the rulers in the Oil Rivers region, Prempeh stood in the way of British imperial interests. Unlike them, he had entered into no treaty with the British, and had not offered any military resistance to them; nor could he be claimed to be in any respect subject to British jurisdiction. His offence was his refusal to surrender effective control of his country to the imperial power. The drive to subdue Asante was driven by colonial officials on the ground, who found the fig leaf of a casus belli to launch an expedition against him, and it was Governor Maxwell who took the decision - on the hoof - to detain Prempeh. Influenced by his memory of Abdullah's treatment, Maxwell's decision to remove Prempeh had nothing to do with any offence he had committed, but was occasioned by his view that it was politically necessary to remove the king, and thereby give a signal to the Asante about the nature of British paramount power. What started as warfare - with Prempeh at first regarded as a prisoner of war by Maxwell - turned to lawfare after an ordinance was hurriedly passed to validate his continued detention. In this process, action which could not be justified under the international law of war was justified by imperial law, which in the process made its own jurisdictional claims over Asante. While officials in London realised that such action might be hard to justify, political expediency drowned out any rule of law concerns.

At the same time, detention was not the only form of 'lawfare' used in respect of Asante. For at the same time that his king was held

${ }^{\text {ror }}$ See A. Adu Boahen, Yaa Asantewaa and the Asante-British War of I900-I (James Currey, Oxford, 2003); and Agbodeka, African Politics and British Policy, pp. $\mathrm{I} 70-\mathrm{I} 8 \mathrm{O}$.

${ }_{102}$ See $\mathrm{CO} 879 / 67 / 3$, No. 38 , p. 65 , reporting on the causes of the rebellion, and how rebels were to be dealt with. The Deputy Governor was instructed to draw up an ordinance to authorise the detention and deportation of forty-seven rebels, who were initially to be held at Elmina Castle. On 25 April I90I, Ordinance No. 4 of I90I (the Ashanti Political Prisoners Detention and Deportation Ordinance) was passed. Fifteen ringleaders were deported to the Seychelles, while thirty-one were held at Elmina. In September, an ordinance was passed, Ordinance I 2 of I9OI, to authorise the detention of another rebel, Kwame Boakye. See CO 879/67/3 enc. 2 in No. 38 , p. 89 ; enc. I in No. 52 , p. I IO; No. 54 , p. I I6; enc. I in No. 84 , p. I69. 
without trial, John Owusu Ansa was tried at the Gold Coast for the ordinary crime of forgery. Maxwell's dual strategy of detention and prosecution may have appeared contradictory: not only did the king's detention without trial acknowledge that he had committed no offence recognised by law, but the prosecution of his envoy as a self-interested impostor might have implied that the king himself was a victim of deception, rather than an obstructive enemy. Yet Maxwell was not concerned to ensure logical consistency in his actions; whereas the detention of the king served a particular political purpose in West Africa, the prosecution of Ansa may rather have been designed to send a signal to anyone in London, who might have had commercial dealings with the king's envoy.

\section{Sierra Leone's Hut Tax War and the Detention of Bai Bureh}

Whereas Asante came under British rule as a result of military operations, imperial authority arrived in the hinterland of Sierra Leone as a result of foreign policy and proclamation. In January I 895 , France and Britain agreed to settle the boundary between the territories under their respective influence adjacent to Sierra Leone. ${ }^{103}$ The following August, an Order in Council, issued under the I 890 Foreign Jurisdiction Act, conferred jurisdiction over territories adjoining the colony, and empowered the Sierra Leone Legislative Council to legislate for them. At the end of August I896, a protectorate was proclaimed over the territory lying on the British side of the line, and ordinances were passed to introduce a new system of administration in these areas. ${ }^{104}$ The protectorate was divided into five districts, each of which had a European District Commissioner who was given jurisdiction over more serious offences involving Africans (for which he sat with assessors) and over all cases which did not involve them (unless the offence was capital, in which case it had to go to the Supreme Court). This new administration had to be paid for, as did the Frontier Police set up by an ordinance in I 890 to keep the peace in an area already referred to as the 'protectorate'. Governor Frederick Cardew,

${ }^{103}$ Christopher Fyfe, A History of Sierra Leone (Oxford, Oxford University Press, I962), p. 524 .

${ }^{104}$ Fyfe, A History of Sierra Leone, p. 54I. 


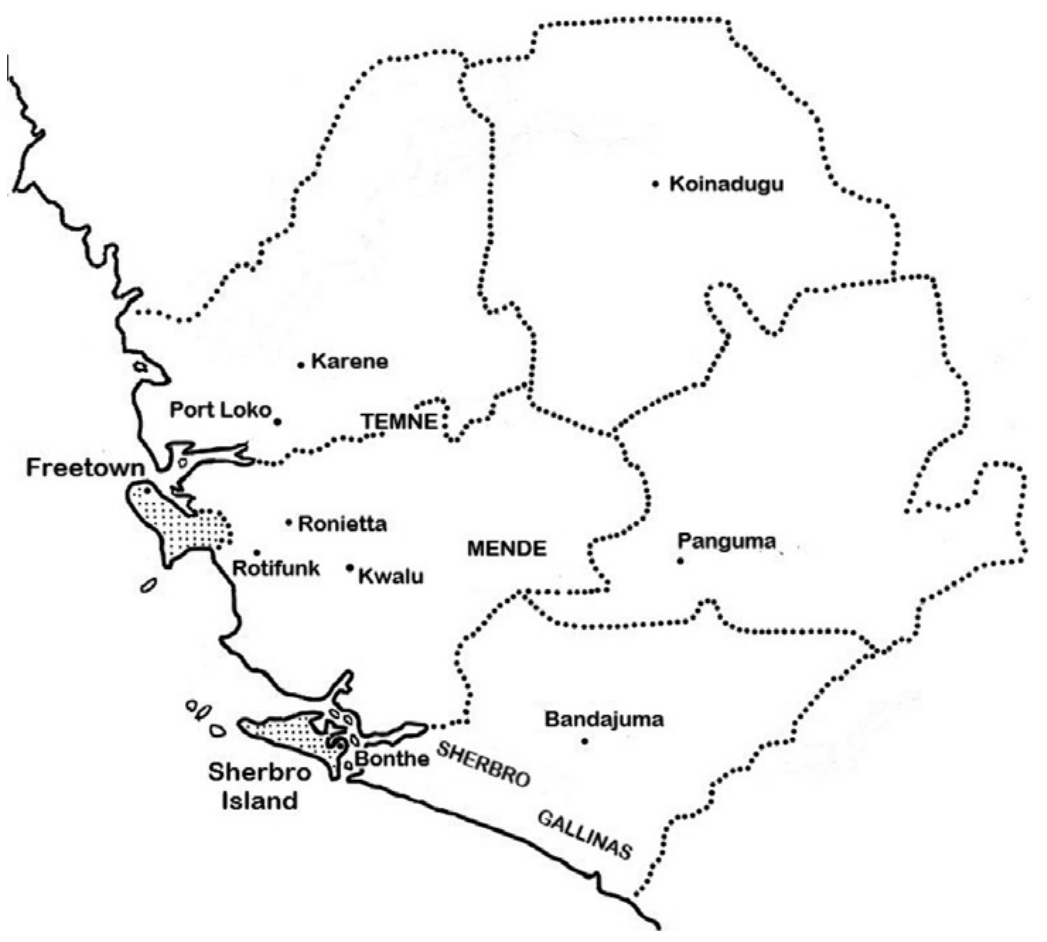

MAP 5 Sierra Leone: Colony and Protectorate

appointed in I 894, thought that the protectorate itself should pay, and so provision was made in the Protectorate Ordinance for the levying of a house tax, as well as the imposition of store and spirit licences. The chiefs were to be responsible for raising the tax, which was to be collected from the beginning of 1898 in three of the five districts Karene, Ronietta and Bandajuma.

Cardew's project for a house tax not only raised eyebrows at the Colonial Office, ${ }^{\text {105 }}$ but also led to protests in Sierra Leone. When the new system was explained to the chiefs in October I 896, ${ }^{\mathrm{IO} 6}$ they were alarmed both by the financial demands and by the British claims to jurisdiction. Many chiefs had never signed treaties of protection, and so did not understand the basis for British claims of authority; and many feared that the claim to tax their homes indicated a claim to the

${ }^{105}$ Fyfe, A History of Sierra Leone, p. 550. ${ }^{106}$ PP I899 (c. 939I) LX. I83, p. 566. 
very property itself. The Freetown press condemned the 'hut-tax' and traders protested against it. ${ }^{\mathrm{I07}}$ In February I897, a group of Mende chiefs led by Gbanna Lewis and Francis Fawundu came to Freetown to petition against the Protectorate Ordinance; and in the middle of the year, a group of Temne chiefs also came to petition against it. ${ }^{\text {I08 }}$ However, Cardew was determined to press ahead with its collection.

\section{The Hut Tax Revolt}

Captain W. S. Sharpe, the District Commissioner in Karene, began to collect the tax on 5 February at Port Loko, the most populous place in the district. Being unable to persuade either the Krio traders or the African chiefs to pay, he first detained the local regent, Bokari Bamp, and then arrested the Krios who were refusing to pay. Sharpe's interpretation of his powers under the Protectorate Ordinance was a generous one: since he had power to distrain property in case of a refusal to pay the tax, and to impose a fine if no property could be found, he felt justified in taking a short cut, simply arresting and detaining non-paying Krios on the assumption that no property would be recovered. Once the tax had been paid, they were released. ${ }^{\text {109 }}$ Having been released after his overnight stay in detention, Bokari Bamp was rearrested and tried with four others for refusing to pay the tax and inciting others to defy the law. The men were sentenced to periods of imprisonment of between twelve and eighteen months after a very summary trial, and on a questionable reading of the ordinance. ${ }^{\text {Io }}$ This show of authority was specifically designed to bring in the tax: for, as Sharpe noted, he intended to ask for Bokari Bamp to be released once the country was quiet and the tax paid. ${ }^{\text {II }}$

When Bokari Bamp was first detained, large numbers of what Sharpe was informed were 'Bai Bureh's war-boys' came to Port Loko from Kasse to effect a rescue. ${ }^{\text {II2 }}$ Sharpe had already heard rumours

\footnotetext{
${ }_{107}$ PP I 899 (c. 939I), pp. 569 ff. $\quad{ }^{\text {ro8 }}$ Fyfe, A History of Sierra Leone, pp. 55 5-556.

109 PP I899 (c. 939I) pp. 205-2I 2.

זо PP I899 (c. 939I), p. 2I2. Sharpe's account is in CO $879 / 55 / 1$, enc. 3 in No. 25 , p. 26.

${ }_{\text {III }}$ CO $879 / 55 /$ I, enc. 3 in No. 25 , p. 26 at p. 29. W. H. Mercer at the Colonial Office minuted, 'Mr. Sharpe seems to have managed matters very smoothly at Port Loko and a word of commendation might be given to him': CO 267/437/63I 5 .

${ }^{112}$ PP I 899 (c. 939I), p. 208.
} 
that Bai Bureh was collecting arms to resist the government; ${ }^{\mathrm{II} 3}$ and he considered this chief to be the main obstacle to the collection of the tax. 'Bai Bureh' was the title held by Kebalai, as chief of Kasse. A war chief and slave raider of Loko descent, Kebalai had been elected to this position in the late $\mathrm{I} 88 \mathrm{os}$. He had been active in the war of succession in the Moria country which had continued for twenty years from the early I 860 s, without ever coming into conflict with the British. It was only after I 890 , when Britain took a more interventionist stance, with a view to bring peace in this area, that he came to their attention. British attitudes to Bai Bureh were ambivalent. On occasion, they found him useful, as in 1892 when he supplied troops for their Tambi expedition against Karimu. ${ }^{\text {II4 }}$ At other times, when his warlike policies threatened to interfere with British interests, they had attempted to arrest him, though without success. ${ }^{\text {II }}$

Convinced that the people were in awe of Bai Bureh, Sharpe thought that it would be impossible to collect the tax successfully unless steps were taken 'to effect his immediate capture' if (as Sharpe assumed) he refused to pay it when summoned to do so. ${ }^{\text {I } 6}$ Cardew agreed that he had to be arrested and deposed. 'He is a great drunkard and a worthless character', he told Chamberlain, 'and it is only by a combination of recklessness and good luck that he has succeeded in giving trouble for such a long time. ${ }^{\mathrm{II}}{ }^{\mathrm{I}} \mathrm{He}$ certainly appeared to be defying the tax. According to Sharpe, a letter sent from Port Loko informing him of a visit to collect the tax was returned with a verbal message 'that the first time I set foot in his town I should be a dead man'. ${ }^{\text {I } 8}$ In response,

${ }^{\text {II3 }}$ District Commissioner to Colonial Secretary, I 2 February I 898, CO 879/55/I, enc. 3 in No. 25, p. 26 at p. 27.

${ }^{114}$ Fyfe, A History of Sierra Leone, pp. 50I-503.

${ }^{115}$ He escaped after being arrested in I 890 (for failing to abide by a peace brokered by the British in a war he had joined against Karimu of Samaia); while in May I 894, another attempt to arrest him (for assisting in raids against territory under French control) failed, and the matter was settled by the imposition of a fine. See 'Bai Bureh's antecedents', CO 267/445/4692; and Fyfe, A History of Sierra Leone, pp. 5OI-503, 522 .

${ }_{116}$ CO $879 / 55 /$ I, enc. 3 in No. 25 , p. 26 at p. 28.

${ }_{117} \mathrm{CO} 879 / 55 / \mathrm{I}$, No. 25 , p. 22 at p. 23.

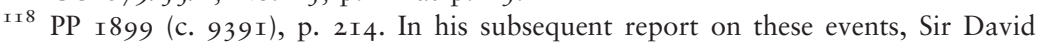
Chalmers found that the original letter had never reached Bai Bureh, but that Sharpe's messenger had been sent back by the chief's war-boys, who would let no one pass: PP I899 (c. 9388) LX. I, p. 36. 
a party was sent out to Romani to arrest Bai Bureh. Arriving on I 8 February, they did not find the chief, but found the town full of warboys. When Sharpe drew blood by hitting one of them on the head, the crowd began to jeer and pelt the police, who decided to withdraw. They were then pursued by the jeering war-boys, and, finding themselves surrounded, fired on the crowd to disperse them. ${ }^{\text {II }}$ Several Africans were killed in this volley, and the war-boys returned fire, though without effecting any casualties. With this exchange, the 'Hut-Tax War' began. Sharpe now felt that a large force needed to be sent to disarm the Africans and take Bai Bureh, dead or alive. As the conflict escalated, Chamberlain minuted 'I am afraid this Hut Tax in its present form was a mistake. But we must wait for peace to reconsider it.' ${ }^{\text {I20 }}$

On 2 March I898, martial law was proclaimed in the Karene District. ${ }^{\text {I2I }}$ Troops started to disarm the people, and repelled attacks, inflicting large casualties on the Africans. With the fire power of the British forces so much greater than that of the Temne, by 9 March Cardew could report that the rebellion was 'very nearly quelled'. ${ }^{\text {I22 }}$ However, the experienced warrior Bai Bureh had built extensive stockades to provide cover for his soldiers, who were able to prolong the conflict by using disciplined guerrilla tactics. ${ }^{\mathrm{I} 23}$ London's response was to authorise the Governor first to raise more Frontier Police, and then to raise troops for a West African Regiment to suppress the revolt. ${ }^{\text {I24 }}$ The troops were able slowly to destroy the stockades and weaken resistance, albeit while suffering some casualties. The most high-profile casualty of the conflict was Rev. William Humphrey of the Church Missionary Society, who was killed at the end of March by insurgents who also mutilated his body. ${ }^{\mathrm{I} 25}$ By the time news of this event had reached Cardew, Bai Bureh was seeking peace. ${ }^{\mathrm{I} 26} \mathrm{He}$ told an intermediary that he had never been asked to pay the hut-tax and had never intended to make war on the government: he had only turned to resistance when the British sent Captain Sharpe 'to take off his head'.

\footnotetext{
II9 See Chalmers' summary of events in PP I 899 (c. 9388 ), pp. 35-40, and the reports by Sharpe and Tarbet, PP I899 (c. 939I), pp. 606-607 and 608-609.

${ }^{20}$ Minute dated I9 March: CO 267/437/62 I 8.

${ }_{\text {I2I }}$ CO $879 / 55 /$, enc. 3 in No. 26, p. 33 . ${ }^{\text {I22 }}$ CO $879 / 55 /$, No. 22, p. 2 I.

${ }^{\mathrm{I} 23}$ Fyfe, A History of Sierra Leone, p. 565.

${ }^{2} 2$ Minute dated 22 March I 898, CO 267/437/6473; CO 879/55/I, No. 36, p. 46.

${ }^{\text {I } 25}$ CO 879/55/I, No. 7I, p. 74. ${ }^{\text {I } 26}$ CO 879/55/I, No. 44, p. 56.
} 
Aware that his forces could never be a match for the British, he intimated that he would seek protection from the French if things continued as they were. ${ }^{127} \mathrm{He}$ also denied any involvement in Humphrey's death, claiming he was not responsible for the war-boys who did it. However, the Governor would not countenance any peace which did not entail the surrender of Bai Bureh and the punishment of Humphrey's killers. ${ }^{\text {I28 }}$

By the middle of May, the rebellion in Karene had been largely suppressed. ${ }^{22}$ Although a number of the ringleaders were detained, Bai Bureh himself remained uncaptured. In June, another attempt was made to broker a peace, but Cardew rejected it, ${ }^{130}$ since he still wanted Bai Bureh's unconditional surrender. At the beginning of October, Bai Bureh again sought to make peace, this time communicating via Freetown Muslims with the special commissioner who had been sent out in July to investigate the causes of the outbreak, Sir David

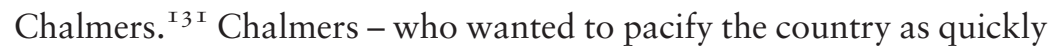
as possible - suggested that the reward offered for Bai Bureh's capture be withdrawn, and that the demand for an 'unconditional' surrender be dropped. ${ }^{\mathrm{I} 32}$ However, his intervention did not go down well with the Governor, who had let it be known that Bai Bureh's life would be spared if he surrendered. ${ }^{133}$ Bai Bureh was finally taken into custody on I I November. ${ }^{\text {I } 34}$

Just as the back of the Temne revolt was being broken, a new uprising erupted on 27 April in the Mende, Sherbro and Gallinas countries. The Mende rising was sudden, co-ordinated and violent. The rebels were bound by a secret oath - the 'one word Poro' - to rise up together, and attack both Europeans and Krio. Missions were attacked and the inhabitants slaughtered, and factories burned down. Any 'alien' who was found was butchered. Reports came in of events such as those at the American mission at Rotifunk, where the missionaries were caught attempting to escape, stripped naked, and marched back to Rotifunk, where they were hacked to death, after one

${ }^{127}$ CO 879/55/I, enc. 4 in No. 7I, p. $77 . \quad{ }^{\text {I2 } 8}$ CO 879/55/I, No. 7I, p. 74.

${ }^{129}$ CO 879/55/I, enc. in No. I39, p. I94. ${ }^{130}$ CO 879/55/I, No. I 22, p. I 56.

${ }^{131} \mathrm{CO} 879 / 55 /$ I, No. I82, p. $264 .{ }_{{ }^{132}} \mathrm{CO} 879 / 55 /$ I, enc. I in No. I 88, p. 273.

${ }^{133}$ Minute, 4 November I 895 , CO 267/440/2378I.

${ }^{134}$ For the circumstances of his capture, see Christopher Fyfe, A Short History of Sierra Leone, new ed. (London, Longman, I979 [1962]), p. I2I. 
of the women had been raped. ${ }^{\mathrm{I} 5}$ Refugees began to flee to Freetown for protection. Unlike the Temne rebellion, this one seemed to have no obvious leader, though there was suspicion that it must have been co-ordinated by the chiefs. The rebellion may also have been encouraged by rumours of Bai Bureh's successes in resisting the British. Cardew was slow to react, and it was only at the start of May that warships were sent to intervene and to remove refugees. ${ }^{136}$ The British also responded by sending two columns of troops, which managed to quell the rebellion by the beginning of July. ${ }^{\mathrm{I} 37}$

\section{The Legal Response}

The Governor and the Colonial Office were already planning their legal response to the Temne rising when the Mende revolt occurred. From the beginning, the plan was to put the rebels on trial. Cardew proposed to enact an ordinance for the 'trial of insurgent bands for capital punishment by [a] Special Commission', thereby avoiding the need to use the ordinary courts. ${ }^{13}{ }^{8} \mathrm{He}$ explained the need for a special commission by drawing attention to two different 'classes' of killings, neither of which could be successfully prosecuted in existing courts. The murder of Rev. Humphrey fell into the first class: he was a European victim, whose killers could only be tried in the colony. The second class comprised the killings of 'Soribonkeh [a] loyal chief, and two natives alleged to have been killed by order of Bai Bureh', whose killers could be tried at a District Commissioner's court including a native chief. ${ }^{\text {I39 }}$ In neither case did Cardew feel he would obtain a conviction. As to the first, it was clear to the colonial authorities that the civilian population of Freetown was opposed to direct taxation and sympathetic to the Temne rebels, and so would not convict. As to the second, it was equally unlikely that an African chief would agree to a conviction.

\footnotetext{
${ }^{135} \mathrm{CO} \mathrm{879/55/I,} \mathrm{No.} \mathrm{IOO,} \mathrm{p.} \mathrm{II} 2$ at p. II3.

${ }^{136}$ See Fyfe, A History of Sierra Leone, pp. 570-577.

I37 See PP I 899 (c. 939I), pp. 633-640.

${ }^{13} 8$ CO $879 / 55 /$ I, No. 48 , p. 60. Chamberlain responded cautiously, stating that the death penalty should be imposed only in cases of murder: CO 879/55/I, No. 52, p. 66.

${ }^{1} 39$ CO $879 / 55 /$ I, No. 53, p. 66.
} 
Chamberlain agreed that punishments should be inflicted in every case for murder or outrage. At the same time, he was far from sure that a special commission would be able to differentiate between acts of murder and acts of war. ${ }^{\mathrm{I} 4 \mathrm{O}}$ While awaiting further information on the proposed special commission, he sent instructions that murder charges should be brought only in cases where the killings would have been treated as murder in peacetime, and not where they had occurred in the context of rioting. Rebel chiefs who could not be charged with 'ordinary' murder should be tried for instigating disturbances, 'unless you consider the case would be better met by passing special detention Ordinances, for which there are many precedents'. As for the ordinary rioters, and chiefs not implicated in any killings, there should be an amnesty. Indeed, Chamberlain wanted to grant a general amnesty as soon as the rebellion had been suppressed, since he was 'strongly inclined to believe that we brought it on ourselves by injudicious legislation \& especially by not making our intentions clear to the natives'. ${ }^{\text {I4I }}$

On 13 April, four days after this telegram was sent, Cardew's despatch containing the draft ordinance to set up the special commission arrived in London. ${ }^{\mathrm{I} 2}$ The draft ordinance did not include any provision as to the legal qualifications either of the president or of the members of the proposed commission - though the Attorney General advised that 'at least the President should be a duly qualified barrister' - and left it to the president to make rules regulating procedure. The commission was to have the power to inflict the death penalty, which could be imposed after a majority verdict (with the president having the casting vote). Clauses were included both to prevent any of its decisions being questioned by habeas corpus and to indemnify anyone acting under its orders from any potential liability. ${ }^{\text {I43 }}$ On seeing the draft, officials were concerned by the proposal that judges appointed on an ad hoc basis should have the power of life and death. Chamberlain's private secretary, H. F. Wilson, suggested enacting alternative legislation, based on the model of a New Zealand statute passed in I 869 to deal with Maori resistance. This measure had allowed

\footnotetext{
${ }^{140}$ As he noted, 'what is murder in warfare? The line is rather difficult to draw': minutes of 27 April I 898, CO 267/438/9094.

ז4I CO 879/55/I, No. 57, p. 68; Minutes of 27 April I 898, CO 267/438/9094.

${ }^{142} \mathrm{CO} 879 / 55 / \mathrm{I}$, No. 60, p. 69 . ${ }^{143}$ The text of the draft is in $\mathrm{CO} 267 / 437 / 9748$.
} 
barristers of seven years' standing to be appointed temporary judges of the Supreme Court to try certain offences within proclaimed areas, and had made provision for juries to be available where expedient. ${ }^{\text {I4 }}$ Wilson felt that some provision needed to be made for the possibility of a jury trial, and that the pool from which commissioners might be drawn needed to be better defined. Bertram Cox agreed that the New Zealand model should be sent to Freetown, though he was convinced by Cardew that the ordinary provisions relating to trial by jury in the colony should not be used, since public opinion in Freetown was so hostile to the tax.

These discussions took place at a point when the Temne revolt seemed to be under control and news of the Mende one had yet to reach London. In the aftermath of the second outbreak, Cardew's policy changed. It was evident that, in the Mende revolt, very many 'ordinary' murders had been committed; and, since a large number of the victims were Krios, there was now little danger of Freetown juries not convicting. However, rather than leaving everything to the Supreme Court (whose civil business would grind to a halt if overloaded with this criminal business), he advised appointing a special commissioner to try murder cases on the spot. ${ }^{\mathrm{I} 5}$ Cardew explained that the two risings needed to be dealt with distinctly. $\mathrm{He}$ was willing to offer an amnesty in Karene, once the rebellion there had been completely suppressed and Bai Bureh captured. In his view, the Temne had conducted the war 'on fairly humane principles', and had generally refrained from killing non-combatants. By contrast, the Mende rebellion had been marked by 'savage barbarism and cruelty', with the rebels killing almost all the Europeans and Krios who fell into their hands. In his view, no amnesty should be offered to the Mende until all those concerned in any murders had been convicted. To re-establish order, it was imperative to act quickly and firmly. ${ }^{146}$

Officials in London debated how to put this into effect. Wilson once more urged a variant of the New Zealand example, suggesting the appointment of a deputy judge to try cases with assessors. Cox did not feel that such emergency legislation was needed. Noting that the

\footnotetext{
${ }^{1} 44$ Disturbed Districts Act I 869 ( 32 \& 33 Vict. c. 20); Minute by Wilson I 2 May I 898, CO 267/437/9748.

${ }^{145} \mathrm{CO} 879 / 55 /$, No. 96, p. I07. ${ }^{146}$ CO $879 / 55 /$ I, No. I 20 , p. I 5 O.
} 
colony had recently passed a Jury Amendment Ordinance (I897), which authorised non-jury trials (with assessors) in non-capital cases, ${ }^{\mathrm{I}} 47$ he suggested that this ordinance could simply be amended by removing the words limiting its operation to non-capital cases, to allow a juryless court to hear murder cases. Officials now favoured the appointment of a deputy judge under existing legislation, who could hear cases on the spot once legislation had been passed to empower Supreme Court judges to sit at any place in the protectorate. ${ }^{\mathrm{I} 48}$ Instructions to this effect were accordingly sent to Cardew. ${ }^{\text {I49 }}$ A procedure was thus put in place to try those accused of outrages during the Hut Tax rebellion, but one which would still follow the procedures of the Supreme Court, rather than an 'emergency' tribunal staffed by non-lawyers, as originally proposed by the Governor. In August, G. A. Bonner, a barrister on the English Midland circuit, was appointed deputy judge to deal with cases outside Freetown, after London had rejected Cardew's recommendation of the former Attorney General of Sierra Leone, Sir Nevill Geary. ${ }^{\mathrm{I} 5}{ }^{\circ}$ At the same time Sir David Chalmers was sent out as a royal commissioner to inquire into the causes of the insurrection and into the state of Sierra Leone. Although legislation was passed to give this commissioner special powers to summon witnesses, it was clear that he would have no part in the judicial proceedings. ${ }^{\mathrm{I}} \mathrm{I}$

In the meantime, an ordinance was also passed 'to empower the Governor to apprehend and detain such persons as he shall suspect of conspiring against Her Majesty's Government'. ${ }^{152}$ By the time this measure had been assented to at the end of May, a number of

${ }^{147}$ The ordinance, which allowed the Attorney General to opt for a non-jury trial, had been passed in response to the acquittal of a number of men who had organised the destruction of a rival church: Fyfe, A History of Sierra Leone, p. 580.

${ }^{148}$ Minutes, I-2 July I 898, CO 267/439/I 4555 .

${ }^{149} \mathrm{CO} 879 / 55 / \mathrm{I}$, No. I23, p. I63. The Supreme Court (Further Amendment) Ordinance $\mathrm{I} 898$ (No. 2) was subsequently passed.

${ }^{150}$ CO 879/55/I, No. I09, p. I42; No. I33, p. I80; No. I36, p. I92; No. I37, p. 192. Regarding Geary, Edward Wingfield minuted 'neither his law nor his common sense is such as to fit him for responsible judicial duties': CO 267/437/9748.

${ }^{15}$ I Ordinance No. 2 I of I 898 , the Special Commission Inquiry Ordinance: CO 879/55/ I, enc. I in No. I49, p. 2 I I. This was modelled on the Dominica Ordinance No. I of I 893 (CO 879/55/I, No. II2, p. I46).

${ }^{1} 5^{2}$ The Insurgents' Temporary Detention Ordinance, No. I 4 of I 898, in CO 879/55/I, enc. I in No. II9, p. I49. 
insurgents who had been captured by the military were being held in Freetown, as well as a few chiefs whose headmen had been prominent in the rebellion. The ordinance was to remain in force only during the course of the rebellion, and Attorney General Smyly indicated in his report that its purpose was to allow the authorities to gather evidence against the detainees pending their trial. ${ }^{\mathrm{I} 33}$ In the view of officials, once a tribunal was in place to try the rebels, detention under the ordinance would no longer be needed. ${ }^{\mathrm{I} 54}$ London had no qualms about sanctioning this ordinance, for Chamberlain had already suggested detention as one option to use against the rebellious chiefs. There had been protests at a public meeting in Freetown on I9 May against extending this measure to the colony - which seemed to cast doubt on the loyalty of the Krios - but the Sierra Leone government was clear that it had to be applied in the colony, for the simple reason that this was where the captured rebels had been taken.

Bonner began to hear cases in October at Kwalu, Bonthe and Bandajuma. At the end of September, sixteen were sentenced to death at Kwalu. ${ }^{155}$ The Colonial Office was content to see these men executed. As W. H. Mercer noted, 'They are all cases of murder of specified persons and no question of law as to the amenability of the prisoners seems to have been involved.' The executions also had a good effect in pacifying the country. ${ }^{156}$ After twenty-one further death sentences had been imposed at Bonthe, Cardew proclaimed a free pardon for those who had taken part in the rising, though this did not (to London's relief) extend to the convicted killers. ${ }^{157}$ At Bandajuma, I07 were tried for murder: 65 were convicted, 35 of whom were given a commuted sentence. ${ }^{158}$ Having finished here, Bonner returned to Bonthe to try more prisoners. In the end, he tried 180 prisoners, of whom 67 were acquitted and I I 2 capitally convicted. ${ }^{159}$ Bonner tried to recommend to mercy as often as possible, but found his assessors in a more hawkish mood. In the end, sixty-six death sentences were confirmed by the Executive Council. It was evident that both the

${ }_{153} \mathrm{CO} 879 / 55 / \mathrm{I}$, enc. 2 in No. I I9, p. I49. ${ }^{154}$ Note by Wilson in CO 267/439/I4542.

${ }^{155} \mathrm{CO} 879 / 55 / \mathrm{I}$, No. I90, p. 287 . One of these sentences was later commuted to life imprisonment.

${ }^{156}$ Minute, 25 November I 898, CO 267/44I/26076.

${ }_{157}$ CO 879/55/I, No. I92, p. 289; No. 207, p. $298 . \quad{ }_{158}$ CO 879/55/I, No. 206, p. 298.

${ }^{159}$ One escaped. CO 879/55/I, enc. in No. 226, p. 3 I7; CO 879/58/8, No. 23 , p. 42. 
Colonial Office and the Governor wanted the Mende rebels prosecuted under the ordinary criminal law for uncontrovertible offences. Cardew had instructed District Commissioners not to commit cases in which the evidence was doubtful, or where the perpetrators were war-boys or slaves acting under the orders of headmen. As a result (as he pointed out), the number of those tried bore a small proportion to the number killed in the insurrection. ${ }^{\text {.60 }}$

\section{Bai Bureh's Capture}

Bai Bureh was captured while these trials were proceeding. Officials in London, who bore in mind Chamberlain's distinction between cases of murder and cases of levying war, and who recalled Cardew's promise to spare his life if Bai Bureh surrendered, were keen not to see him capitally charged. ${ }^{\mathrm{I} \text { I }}$ Cardew's proposal that he be tried by Deputy Judge Bonner with assessors at Karene for treason or treason-felony, but with no question of the death penalty being imposed, ${ }^{162}$ did not resolve their concerns. Edward Fairfield thought it would be prudent to ask the Law Officers whether Bai Bureh could be considered a British subject for the purposes of the treason laws, since it would be 'very awkward' if Bonner were to take the view at trial that he was not, or if Bai Bureh were to challenge any conviction in the Privy Council. ${ }^{{ }^{6} 3}$ Cardew was accordingly instructed to suspend all action against Bai Bureh until the Law Officers had responded. The question referred to them by the Colonial Office made no assumption that Sierra Leone had become a territory of the crown by virtue of being proclaimed a protectorate or that its inhabitants were subject to the crown's jurisdiction - though these were the very assumptions which lay behind the Foreign Office's approach to troublesome protected rulers in the Niger Delta. The Law Officers, Richard Webster and Robert Finlay, were asked to consider the position of an African chief residing

\footnotetext{
I60 O 879/55/I, No. 226, p. 316.

I6I Minute by Mercer, I4 November I 898, CO 267/44 I/25645.

${ }^{162} \mathrm{CO} \mathrm{879/55/I,} \mathrm{No.} \mathrm{I96,} \mathrm{p.} \mathrm{29I.} \mathrm{Ernest} \mathrm{J.} \mathrm{Watts,} \mathrm{who} \mathrm{had} \mathrm{defended} \mathrm{the} \mathrm{accused} \mathrm{in} \mathrm{the}$ murder trials, offered to defend Bai Bureh should he be prosecuted: Watts to Chamberlain, 6 December I 898, CO 267/444/27654. No member of the Freetown bar was prepared to act, since the fees paid were so low: CO 267/447/2I 435 .

I63 Minute I6 November I 898, CO 267/44I/25785.
} 
in a protectorate in which British subjects had been given the right to trade and travel through treaties with the chiefs, and in which British jurisdiction had been exercised 'entirely by usage and sufferance of the chiefs and people themselves'. They were also instructed that, in Sierra Leone, English law as it stood in 1880 was introduced into the colony in I 889 (insofar as local conditions allowed), which meant that English treason laws were in force there. Jurisdiction had also been extended over the protectorate under the Foreign Jurisdiction Act (and it was under this jurisdiction that the murder trials had been held).

The Law Officers reported on 25 November that Bai Bureh could not be tried for treason, since the protectorate could not be considered to be part of the Queen's dominions, and Bai Bureh was not a British subject. ${ }^{164}$ While it was settled that someone who was not a subject could be tried for treason committed within the Queen's dominions (under the doctrine of local allegiance), and that a subject could be tried for treason committed outside the crown's dominions, they considered Bai Bureh to fall into neither category. ${ }^{165}$ They advised, however, that Bai Bureh might be prosecuted either for murder (if there was evidence against him on that charge), or under the general article 67 of the I897 Protectorate Ordinance, which allowed an unlimited penalty for disobeying instructions. ${ }^{166}$ They also recommended passing an ordinance to criminalise levying war or offering armed resistance against the protectorate government. This advice in effect

${ }^{164}$ In I 855 , an earlier set of law officers had given an opinion that natives of the Ionian Republic - who lived under British protection - could not be regarded as subjects who might be liable for treasonable acts committed in aiding the enemy during the Crimean War: Opinion dated Io May I 855, CO 885/3/I No. 57, p. 62.

${ }^{165} \mathrm{CO} 879 / 55 /$ I, No. 202, p. 294. They distinguished the case of Dr Leander Jameson, who was tried in I 896 under the Foreign Enlistment Act of I 870, which criminalised preparing military expeditions against a friendly state from within British dominions, for his acts in preparing the Jameson Raid on the South African Republic from the Barolong area of Bechuanaland. In that case (they explained), it was held that 'a Protectorate was part of Her Majesty's dominions for the purposes of the Foreign Enlistment Act' rather than treason. In fact, British Bechuanaland (in which the activity had taken place) had been annexed to the Cape Colony, and was distinct from the Bechualanand Protectorate which lay north of the Molopo River. See The Times, 25 July I 896, p. I4 and The Queen v. Jameson [1 896] 2 QB 425.

${ }^{166}$ Article 67 of Ordinance II of I 897 (the Protectorate Ordinance) enacted that 'any Chief who shall be ordered by the Governor either directly or by a deputy or messenger to do or refrain from doing any public act or acts and shall either defy or neglect promptly to obey such order shall be guilty of an offence.' 
scuppered the plans to put Bai Bureh on trial. Since there had been no suggestion hitherto that he was directly implicated in any murder, Wingfield ruled this option out. He preferred 'to deal with Bai Bureh as a political prisoner and pass an ordinance authorizing his detention as has been done before with other refractory Chiefs', rather than prosecuting him under the Protectorate Ordinance. ${ }^{167}$ Chamberlain was inclined to be more lenient. Given that the protectorate was only newly established, he thought it was natural that there should be discontent which might break out into insurrection. Since Bai Bureh was clearly a man of influence, 'it could be better to use him if possible than to lock him up', perhaps imposing a fine and giving him a warning about his future conduct. ${ }^{\mathrm{I} 68}$

Faced with the three choices, Cardew opted to detain Bai Bureh as a political prisoner. ${ }^{169}$ An ordinance was passed in December authorising his detention and deportation, and indemnifying those involved in his capture and detention from any legal action. ${ }^{\mathrm{I} 0}$ The report of the Attorney General on this legislation did not explain why it was necessary to detain Bai Bureh, beyond saying that he had been engaged in acts of rebellion against the government. Two months after the ordinance had been passed, Cardew sent London a memorandum on 'Bai Bureh's antecedents', which described his activities over a decade, but said little about his actions during the Hut Tax war, beyond the comment that he 'was leading and directing the insurgents'. Reading this document, Selborne noted, 'This record does not seem to me to be what can reasonably be called a bad one in a native chief'. ${ }^{17 \mathrm{I}}$ Chalmers also took a much more lenient view of Bai Bureh's actions than did the Governor. In his report on the crucial event which sparked Bai Bureh's resistance - the attempt to arrest him - Chalmers concluded that the chief had not given the defiant response attributed to him by Captain Sharpe, and that 'the arrest of Bai Bureh which was

${ }^{167}$ Minute, 26 November I 898, CO 267/443/26666.

I68 Minute, 27 November I898, CO 267/443/26666.

I69 CO 879/55/I, No. 206, p. 298; No. 2 II, p. 300; No. 219, p. 309.

${ }^{170}$ Ordinance No. 39 of I 898 , 'The Political Prisoner's (Bai Bureh) Ordinance, I 898 , CO $879 / 58 / 8$, enc. I in No. I4, p. Io. He was initially held in Karene, but moved to Freetown in February after one of his guards tried to help him escape. Fyfe, A History of Sierra Leone, p. 594.

I7I Cardew to Chamberlain, Io February I 899, CO 267/445/4692. This was written in response to a request from London: $\mathrm{CO} 879 / 58 / 8$, No. 3 , p. 4 . 
intended, and the attempt to effect which led to the collision, was aggression pure and simple on the part of the authorities.' ${ }^{172}$ Nonetheless, when the acting Governor, Major Matthew Nathan, reviewed his detention in April, he did not recommend his release: Bai Bureh was 'one of the most successful of the insurgent chiefs' and it was in the interest of peace 'that it should be known that such defiance receives severe punishment'. ${ }^{173}$

By April I 898, a number of other chiefs had also been detained under special ordinances. They included a number of Temne rebels who had been convicted in the District Commissioner's court for levying war, but whose convictions were regarded as void, in light of the Law Officers' advice. ${ }^{174}$ They also included Nyagwa, the chief of Panguma. ${ }^{175}$ Although Panguma was not one of the areas in which the hut tax was to be paid, the Acting District Commissioner in the area, J. E. C. Blakeney, reported in April that Nyagwa was suspected of making preparations for war to 'drive the white man out of his country'. ${ }^{176}$ After demanding that he surrender all his arms, Blakeney arrested him in early May. ${ }^{177}$ Hostilities now broke out in this area, and attempts were made to rescue Nyagwa. ${ }^{178}$ Nyagwa was charged with conspiracy to levy war and sentenced by Blakeney to banishment for fourteen years under the Protectorate Ordinance of $1897 .{ }^{179}$ Then, in July, he was moved from Panguma to Freetown, where he was

${ }^{172}$ PP I 899 (c. 9388), p. 38 (emphasis in original).

${ }^{173} \mathrm{CO} 879 / 58 / 8$, No. 36 , p. 82 at p. 83.

${ }^{174}$ They included Bai Bureh's ally Alimami Lahai, Bai Kura Hari and Bai Forki: CO $879 / 58 / 8$, enc. in No. 36 at pp. $87-88$. Ordinance No. 8 of I 899 , Political Prisoners' Ordinance (No. 3) I 899, CO 879/58/8, enc. I in No. 35, p. 8I. As Antrobus put it, 'The ordinance is in the usual terms: it was necessary to provide for the detention of these persons': CO 267/446/IOI48.

${ }^{175}$ He was well known to the Sierra Leone government, having briefly sheltered Makaia during the Yoni disturbances of I889, before handing him over. He had also cooperated with the British on a number of other occasions: Fyfe, A History of Sierra Leone, pp. 518-52 I; CO 879/58/8, enc. in No. 36, p. 84.

${ }^{176} \mathrm{CO} 879 / 55 / \mathrm{I}$, enc. in No. 6I, p. 70 at p. 7 I.

${ }_{177} \mathrm{CO} 879 / 55 /$ I, enc. 3 in No. 87 , p. 87 ; enc. in No. 36 , pp. $84-85$; Blakeney remained convinced that Nyagwa had supplied most of the men and materiel for the fighting in Bandajuma: See CO 879/55/I, No. I29, p. I68; No. 95, p. I05 at p. I07.

${ }_{178} \mathrm{CO} 879 / 55 / \mathrm{I}$, enc. in No. I 54, p. 216 at p. 217.

179 Section 68 of Ordinance I I of I 897 (the Protectorate Ordinance) enacted that 'any person who resists or with others conspires to resist the execution of any process of law or to overawe by force or show thereof any public officer in the exercise of his duty shall be guilty of an offence.' 
detained under the Insurgents' Temporary Detention Ordinance of I 898. Although it was intended to prosecute him for murder, no charge was brought, and at the end of February I 899, his continued detention (or deportation) was provided for in the Political Prisoners' Ordinance of $1899 .{ }^{\text {I80 }}$

The government also used special ordinances to detain Mende leaders. The most prominent of these was Gbanna Lewis, Bai Sherbro of Yoni, ${ }^{18 \mathrm{I}}$ who was thought to be behind the resistance to the hut tax. He was one of the chiefs who had gone to Freetown in I 897 to protest against the Protectorate Ordinance; and he had subsequently organised a Poro to boycott European trade (a practice which was soon banned by an ordinance). He was also thought to be behind the 'one word Poro' which led to the Mende uprising. He was arrested on 7 May I 898, and 'treated as a suspect' (as Chalmers put it in his report), although there seemed to be no evidence against him. ${ }^{\mathrm{I} 82}$ The ordinance under which he was detained (No. 3 of I 899) also provided for the detention of Bimba Kelli, another one of the Mende chiefs who protested in Freetown in February 1897. He had been arrested in June I 898, and had been twice tried and acquitted for murder. He was re-arrested at the request of the District Commissioner at Bonthe, who considered that his continued presence in the Imperri country would be dangerous. ${ }^{\mathrm{I} 3}$ The Colonial Office approved this ordinance, but reiterated its view that 'political prisoners should not be detained longer than is absolutely necessary' and that there should be reports on them every six months. ${ }^{.84}$

\section{Continuing the Detentions}

On 17 January 1898 , a general amnesty was proclaimed, which exempted only those in custody and awaiting trial, and those involved in the killing of Humphrey and two African chiefs. ${ }^{185}$ With the war over, and an amnesty proclaimed for rebels, the question was begged whether the detainees should be released. The Colonial Office

\footnotetext{
ז80 Ordinance No. 3 of 1899 , which also provided for the detention of Gbanna Lewis (Bai Sherbro) and Bimba Kelli. CO 879/58/8, enc. I in No. 29, p. 46.

18I For his background, see Fyfe, A History of Sierra Leone, p. 556.

${ }^{182}$ PP I 899 (c. 9388), p. 49. I83 CO 879/58/8, enc. in No. 36, at pp. 87-88.

${ }^{1} 84$ Minute by Antrobus, CO 267/445/7I 24. ${ }^{185}$ CO 879/58/8, enc. in No. 20, p. 4I.
} 
was particularly concerned about the treatment of Bai Bureh, since both Chamberlain and Chalmers took a more benevolent view of his actions than did Cardew. In March, press reports reached London that Bai Bureh had refused to eat the prison food, and was asking for different treatment from that usually accorded to prisoners. ${ }^{186}$ Responding to them, Cardew explained that he was being kept separately from other prisoners and given a special diet. At the same time, he proposed deporting Bai Bureh to Gambia or the Gold Coast. ${ }^{187}$ This proposal did not go down well in London. While Mercer accepted that there was in effect nowhere to keep Bai Bureh in Freetown apart from the prison, he thought that this hardly necessitated his deportation. His hope was that the incoming Acting Governor, Nathan, would 'be able to secure him as what he was formerly, an ally'. Wingfield also hoped he could be released before long, and Chamberlain refused to countenance his deportation until he had decided on the recommendations in Chalmers's report. ${ }^{\text {I }}{ }^{\text {h }}$

In April, Nathan reviewed the cases of all seven chiefs still confined in Freetown gaol. Although he opposed Bai Bureh's release, he recommended freeing both Bai Kura Hari and Nyagwa. While he considered the former not to be a chief of any particular importance, he noted that the latter had done good service for the government on previous occasions. In addition, Nathan thought that the suspicions against Nyagwa which had led to his arrest (before the rebellion broke out in his area) were exaggerated, and he worried that the Panguma district was 'disorganised' by this important chief's absence. As for the other four, he recommended their continued detention. Nathan thought that there was evidence that Gbanna Lewis had been 'largely responsible' for the Mende uprising; but in any case, since he had long been a disruptive influence, it would pose too great a risk to the peaceful trade of Sherbro to release him. Although Alimami Lahai was much less important, he was a chief whose influence, like Bai Bureh's, rested largely on his reputation as a warrior, and 'we do not wish to give scope to his talents in that direction.' Bai Forki and Bimba Kelli were also to remain in detention because their influence might be

\footnotetext{
${ }_{186}$ Morning Post, 7 March I899, p. $7 . \quad{ }_{187}$ CO 879/58/8, No. 26, p. 45 ; No. 27 , p. 46.

${ }^{188}$ Minutes, 9 March I 899, CO 267/445/5870; Cardew was instructed on the next day to take no steps in respect of deportation until Chamberlain had considered the report. CO $879 / 58 / 8$, No. 28 , p. 46.
} 
used to bad effect. ${ }^{189}$ Although Nathan felt that all of these men had been detained under ordinances as a result of the Law Officers' opinion that they could not be tried for treason or treason-felony, his reasons for keeping them incarcerated had more to do with his concern about their future influence than their past conduct. His recommendation to London was that Bai Bureh, Bai Sherbro of Yoni and Bai Forki should be banished to the Gold Coast, and that Alimami Lahai and Bimba Kelli should be kept in Freetown prison 'for a year or two'. Although officials in London were minded to follow these recommendations, the Colonial Office was markedly less hawkish than officials in West Africa: Edward Wingfield expressed a hope that they could all be released before long, while Chamberlain minuted, 'I am sorry that Major Nathan does not see his way to recommend the restoration of Bai Bureh who has rather enlisted my sympathy. ${ }^{\text {'190 }}$

The hawkish approach of the West African officials was soon manifested in overturning the decision to release Nyagwa and reinstate him as Paramount Chief. When the matter was referred to Cardew (on leave in London), he saw no reason for any leniency towards this chief, whom he regarded not only as 'a notorious drunkard, and a savage and cruel ruler', but also as 'a powerful factor in the rising. ${ }^{\text {' }}{ }^{19}$ In the meantime, Nathan had received a further report on Nyagwa from Captain Birch, the District Commissioner in Panguma, which argued that releasing this chief would be taken as a sign of weakness by the Africans, who had got the idea that the British never punished, but merely detained people for a short time and then released them. ${ }^{192}$ In light of this report, Nathan changed his recommendation, and now urged that Nyagwa be deported, along with Bai Bureh and Gbanna Lewis. ${ }^{193}$ Chamberlain's reaction summed up the reaction of the Colonial Office: 'I very much regret the decision, but in view of this strong report I have no choice. ${ }^{\text {'94 }}$ Their deportation to the Gold Coast was duly authorised, and at the end of July (by which point the Gold Coast had passed the necessary legislation to receive them), Nyagwa, Bai Bureh and Gbanna Lewis left Freetown for the Gold Coast. Bai Bureh remained in the Gold Coast until 1905, when he was allowed to return

\footnotetext{
${ }_{189} \mathrm{CO} 879 / 58 / 8$, No. 36, pp. 82-83. $\quad{ }_{190}$ Minute of I6 May I 899, CO 267/446/10395.

191 CO $879 / 58 / 8$, No. 4 O, p. 89 . ${ }^{192} \mathrm{CO} 879 / 58 / 8$, enc. I in No. 44 , p. $9 \mathrm{I}$.

${ }^{193} \mathrm{CO} 879 / 58 / 8$, No. 44 , p. 9 I.

${ }^{194}$ Minute, 28 June I 898, CO 267/446/I 5653 . See also CO 879/58/8, No. 46, p. 93.
} 
to Sierra Leone and reinstated as chief. The other two men did not live to see their homelands again, Nyagwa dying at the Gold Coast in I906, and Gbanna Lewis six years later. ${ }^{\text {I95 }}$

Although, like Prempeh, Bai Bureh was eventually detained by virtue of an ordinance, the approach taken in his case contrasted strongly with that taken in that of the Asantehene. Bai Bureh was not the ruler of a kingdom who stood in the way of British expansion, but a rebel against a new British system of administration. When dealing with rebels against the new protectorate, the Colonial Office was determined to proceed by ordinary legal means, and sought to avoid reliance on 'exceptional' methods, such as the creation of an ad hoc tribunal. It was as a result of their concern that the legal steps they were taking would be watertight that officials asked the Law Officers whether Africans in the protectorate could be regarded as subjects, liable to charges of treason; and it was only in response to the Law Officers' advice that they could not be so regarded that the decision was taken to detain Bai Bureh by ordinance.

The decision not to attempt to prosecute Bai Bureh under the Protectorate Ordinance also raises a contrast with the treatment of Nana Olomu. In Nana's case, the colonial authorities were none too worried about the precise nature of the charges brought against him on the basis of the Africa Order in Council of I 893, and nor were officials at the Foreign Office concerned with looking too closely at whether this instrument would bear the gravity of the charges against him. By contrast, in Bai Bureh's case, where officials were aware that he could be charged under the Protectorate Ordinance, they came to the rapid conclusion that, as Wingfield put it, 'it is scarcely adequate to treat such action as that of Bai Bureh as merely disobedience to lawful orders or resistance to process of law. ${ }^{\text {I96 }}$ Both he and his political masters preferred to detain Bai Bureh via an ordinance rather than to try him on charges which would not signal the gravity of his alleged offence. In taking this approach, officials in London may have wanted to avoid

195 Fyfe, A History of Sierra Leone, pp. 594-595.

${ }^{196}$ Minute dated 26 November I $898, \mathrm{CO} 267 / 443 / 26666$. He noted this even though he was aware that the ordinance set no limits to terms of imprisonment, and may also have been aware of the provision (Article 77 of Ordinance II of I897) which allowed District Commissioners to banish anyone from their district in the interests of 'security, peace or order'. 
being seen to stretch the new legal system; equally, they may have wanted to retain a level of flexibility in dealing with Bai Bureh, whom Chamberlain wanted to be released as early as was possible. If the end result for Bai Bureh was the same kind of ordinance as that which detained Prempeh, the officials who endorsed it clearly felt that the demands of due process needed to be taken more into account in a territory where they were seeking to build a new legal system than in locations of conquest.

\section{Conclusion}

The contrast between these cases suggests that the more territories were perceived to be under imperial control, the more aware the Colonial Office became of the need to use ordinary forms of law to deal with political offenders. Nor was it long before Asante, whose constitutional position remained initially ambiguous after Prempeh's fall, came to be more formally under imperial control. Asante was not annexed in 1896 , though a British Resident remained in Kumasi, exercising criminal and civil jurisdiction. In I899, the Gold Coast's Chief Justice, Brandon Griffith, argued that it should be regarded as part of the colony (along with the other protected areas south of the Prah). ${ }^{197}$ The Law Officers in London disagreed with his view of the law, holding that the Gold Coast's legislature did not have any jurisdiction over Asante. ${ }^{198}$ The Colonial Office now wanted an Order in Council, in order to put the crown's jurisdiction in Asante on a firm footing, and gave instruction for an Asante Protectorate Order in Council to be issued. However, Asante was annexed after the war of I900, by imperial Order in Council of 26 September I90I, which declared that it had been conquered. Asante now became a colony, separate from the Gold Coast, whose Governor was empowered to exercise all the legislative and judicial powers of the crown in Asante. Another Order in Council (of the same date), issued under the Foreign Jurisdiction Act I 890, provided for the government

197 Griffith Memorandum, 9 August I899, CO 879/62/10, enc. 5 in No. 4, p. 8; cf. David Kimble, A Political History of Ghana, I850-1928 (Oxford, Oxford University Press, I963), p. 3 I6.

${ }^{198}$ Chamberlain to Hodgson, I9 February I900, CO 879/62/Io, enc. 5 in No. 7, p. I 5 ; cf. Kimble, A Political History of Ghana, p. 316. 
of the 'Northern Territories', African polities north of Asante with which the British had signed treaties. Although accorded the status of a Protectorate, the structure of government here was very similar to that of Asante. ${ }^{199}$ Asante and the territories north of it were now formally within the British imperial sphere, as was Sierra Leone.

With the defeat of Yaa Asantewaa's Asante warriors and the suppression of the Hut Tax revolt in Sierra Leone, ad hominem ordinances to detain and deport political prisoners in these areas fell into disuse, after a twenty-year period in which on average more than one had been passed every year. They had been important tools of control at a time when the extent of British jurisdiction over these enemies was unclear, and when there was strong resistance to British encroachment. However, in the new dispensation in the decade that followed, tailor-made ordinances to remove particular opponents fell out of use, even if West Africa would continue to see the deposition and removal of chiefs under general ordinances which gave great discretion to the executive. ${ }^{200}$

199 Kimble, A Political History of Ghana, pp. 324-325.

200 See esp. the Nigerian Deposed Chiefs Removal Ordinance, No. 59 of I9I7: see Tunde Oduwobi, 'Deposed Rulers under the Colonial Regime in Nigeria: The Careers of Akarigbo Oyebajo and Awujale Adenuga', Cahiers d'études africaines, vol. I7I (2003), pp. 553-57I; Bonny Ibhawoh, Imperialism and Human Rights: Colonial Discourses of Rights and Liberties in African History (Albany, State University of New York Press, 2007), pp. 67-68; and Bonny Ibhawoh, Imperial Justice: Africans in Empire's Court (Oxford, Oxford University Press, 20I3), ch. 5, discussing the case of Eshugbayi Eleko, removed from Lagos in 1925, resulting in a challenge in the Privy Council: Eshugbayi Eleko v. the Officer Administering the Government of Nigeria and Another [193I] AC 662. 